\title{
Interpretation of lineaments and faults near Summerville, South Carolina, USA, using LiDAR data: implications for the cause of the 1886 Charleston, South Carolina, earthquake
}

\author{
Ronald T. Marple et James D. Hurd
}

Volume 56, 2020

URI : https://id.erudit.org/iderudit/1069657ar

DOI : https://doi.org/10.4138/atlgeol.2020.003

Aller au sommaire du numéro

Éditeur(s)

Atlantic Geoscience Society

ISSN

0843-5561 (imprimé)

1718-7885 (numérique)

Découvrir la revue

Citer cet article

Marple, R. \& Hurd, J. (2020). Interpretation of lineaments and faults near Summerville, South Carolina, USA, using LiDAR data: implications for the cause of the 1886 Charleston, South Carolina, earthquake. Atlantic Geology, 56, 73-95. https://doi.org/10.4138/atlgeol.2020.003
Résumé de l'article

LiDAR (light detection and ranging) data acquired near Summerville, South Carolina, reveal numerouslineaments trending in various directions across the Middleton Place-Summerville seismic zone (MPSSZ) andsurrounding area.

These lineaments are defined by linear depressions and stream valleys that are developed withinlate Eocene to Holocene marine, marginal marine, and fluvial sediments of the Atlantic Coastal Plain. The 40-kmlong,ENE-WSW-oriented Deer Park lineament coincides with the Woodstock epicenter of the 1886 Charlestonearthquake, suggesting that the main shock may have occurred along a fault associated with this lineament. Theproximity of the 17-km-long, ENE-WSW-oriented Middleton Place lineament to the Middleton Place epicentersuggests that it too may have ruptured in 1886. Several E-W-oriented topographic scarps are also located nearthe area of modern seismicity, including the 3- to 5-km-long, south-facing McChune and Summerwood scarps.The McChune scarp is aligned with the $\mathrm{E}-\mathrm{W}$-trending portion of the Summerville scarp to the west, suggestingthat both scarps may be from uplift to the north along the same fault. The McChune scarp and the Otranto andMiddleton Place lineaments coincide with faults interpreted from previously acquired seismic-reflection profiles,suggesting that these features are surface expressions of Quaternary faults. Other lineaments east of the MPSSZare associated with Neogene structural domes, indicating that the interpreted faults along these lineaments havebeen active during the late Cenozoic. The LiDAR data also revealed a $\sim 350$-m dextral offset of a mid-Pleistocenebeach ridge along the Woodstock fault and a 20-km-long, NW-SE-oriented lineament to the east (Canterhilllineament) that appears to be the surface expression of the Charleston fault. 


\title{
Interpretation of lineaments and faults near Summerville, South Carolina, USA, using LiDAR data: implications for the cause of the 1886 Charleston, South Carolina, earthquake
}

\author{
Ronald T. MARple ${ }^{1}$ AND James D. Hurd, JR. ${ }^{2}$ \\ 1. 403 Wickersham Avenue, Fort Benning, Georgia 31905, USA \\ 2. Department of Natural Resources and the Environment, The University of Connecticut, \\ 1376 Storrs Road, Storrs, Connecticut 06269-3087, USA \\ Corresponding author <ronmarple@verizon.net>
}

Date received: 10 January 2020 gate accepted: 12 April 2020

\begin{abstract}
LiDAR (light detection and ranging) data acquired near Summerville, South Carolina, reveal numerous lineaments trending in various directions across the Middleton Place-Summerville seismic zone (MPSSZ) and surrounding area. These lineaments are defined by linear depressions and stream valleys that are developed within late Eocene to Holocene marine, marginal marine, and fluvial sediments of the Atlantic Coastal Plain. The 40-kmlong, ENE-WSW-oriented Deer Park lineament coincides with the Woodstock epicenter of the 1886 Charleston earthquake, suggesting that the main shock may have occurred along a fault associated with this lineament. The proximity of the 17-km-long, ENE-WSW-oriented Middleton Place lineament to the Middleton Place epicenter suggests that it too may have ruptured in 1886. Several E-W-oriented topographic scarps are also located near the area of modern seismicity, including the 3- to 5-km-long, south-facing McChune and Summerwood scarps. The McChune scarp is aligned with the E-W-trending portion of the Summerville scarp to the west, suggesting that both scarps may be from uplift to the north along the same fault. The McChune scarp and the Otranto and Middleton Place lineaments coincide with faults interpreted from previously acquired seismic-reflection profiles, suggesting that these features are surface expressions of Quaternary faults. Other lineaments east of the MPSSZ are associated with Neogene structural domes, indicating that the interpreted faults along these lineaments have been active during the late Cenozoic. The LiDAR data also revealed a $\sim 350-\mathrm{m}$ dextral offset of a mid-Pleistocene beach ridge along the Woodstock fault and a $\sim 20$-km-long, NW-SE-oriented lineament to the east (Canterhill lineament) that appears to be the surface expression of the Charleston fault.
\end{abstract}

\section{RÉSUMÉ}

Les données acquises par télédétection par laser (LiDAR) dans la région de Summerville en Caroline du Nord révèlent de nombreux linéaments se refLétant dans diverses directions à travers la zone sismique Middle PlaceSummerville (ZSMPS) et ses environs. Ces linéaments sont définis par des dépressions linéaires et des vallées de cours d'eau qui sont développées dans les sédiments marins, de la marge continentale et fuuviaux de l'Éocène tardif à l'Holocène de la plaine côtière de l'Atlantique. Le linéament de Deer Park, d'une longueur de $40 \mathrm{~km}$ et orienté ENE-OSO, coïncide avec l'épicentre de Woodstock du tremblement de terre de Charleston en 1886, ce qui suggère que la secousse principale peut s'être produite le long d'une faille associée à ce linéament. Le linéament de Middleton Place de $17 \mathrm{~km}$ de long et orienté ENE-OSO est situé à proximité de l'épicentre de Middleton Place, suggérant qu'il a lui aussi pu se rompre en 1886. Plusieurs escarpements topographiques orientés est-ouest sont également situés près de la zone de sismicité moderne, notamment les escarpements McChune et Summerwood, chacune de longueur allant de 3 à $5 \mathrm{~km}$ et exposés plein sud. Plus à l'ouest, l'escarpement de McChune est aligné avec la partie à tendance est-ouest de l'escarpement de Summerville, ce qui suggère que les deux escarpements peuvent s'être soulevés vers le nord le long de la même faille. L'escarpement de McChune et les linéaments Otrante et Middleton Place coïncident avec des failles interprétées à partir de profils de réfLexion sismique précédemment acquis, suggérant que ces caractéristiques sont des expressions de surface de failles quaternaires. D'autres linéaments à l'est de la ZSMPS sont associés à des dômes structuraux néogènes, ce qui indique que les failles interprétées le long de ces linéaments ont été actives au Cénozoïque tardif. Les données LiDAR ont également révélé un mouvement dextre d'environ $350 \mathrm{~m}$ d'une crête de plage du Pléistocène moyen le long de la faille de Woodstock et un linéament d'environ $20 \mathrm{~km}$ de long, orienté NO-SE à l'est (linéament de Canterhill), qui semble être l'expression en surface de la faille de Charleston.

[Traduit par la redaction] 


\section{INTRODUCTION}

The main shock of the 1886 Charleston, South Carolina, earthquake was the largest historical earthquake to have occurred along the Atlantic seaboard of the eastern United States. Moment magnitude estimates of the earthquake range from $M_{w} 6.9$ (Bakun and Hopper 2004) to $M_{w} 7.3$ (Johnston 1996). Most of the recent seismicity is located within the Middleton Place-Summerville seismic zone (MPSSZ), with the greatest concentration along the Ashley River valley northwest of Middleton Place (Fig. 1). No exposures of fault planes have been located in the area, except possibly for a $10-\mathrm{cm}$ left-lateral offset of the northern and southern walls of Old Fort Dorchester near the northern side of the Ashley River valley (Talwani et al. 2011). Contemporary reports suggest that as many as three epicenters may have been associated with the 1886 Charleston earthquake: one near Woodstock that is thought to have been associated with the main shock, a second epicenter west of Rantowles, and a third one near Middleton Place (Dutton 1890; McKinley 1887) (Fig. 2).

Several models have been proposed to explain the 1886 Charleston earthquake and modern seismicity. Using an integration of river morphology, seismic-reflection profiles, and other geological data, Marple and Talwani (2000) hypothesized that the earthquake occurred along the southern end of the $\sim 200-\mathrm{km}$-long, NNE-SSW-trending Woodstock fault (Fig. 1). The Woodstock fault dips steeply to the west and is associated mainly with right-lateral strike-slip displacements (Talwani 1982). Marple and Miller (2006) postulated that the Charleston earthquake and MPSSZ are associated with a $12^{\circ}$ bend in the Woodstock fault as shown in Figure 1. Talwani and Dura-Gomez (2009), in contrast, hypothesized that the MPSSZ is associated with a $\sim 6 \mathrm{~km}$ rightstep offset in the Woodstock fault along the Ashley River. More recently, Chapman et al. (2016) postulated that the Charleston earthquake occurred on a west-dipping, NNESSW-trending reverse fault.

Our goal was to search for evidence of surface faults in the MPSSZ and surrounding area using mainly LiDAR data and previously acquired seismic-reflection data. Our results suggest that the main shock of the 1886 Charleston earthquake may have occurred along the 40-km-long, E-W-oriented Deer Park lineament. They also suggest that the MPSSZ is associated with several intersecting faults oriented in various directions east of the bend in the Woodstock fault. A 350-m right-lateral offset of a middle Pleistocene beach ridge along the Woodstock fault northeast of Summerville suggests that the fault has locally broken the ground surface numerous times in the past (Marple and Hurd 2020). Lastly, our study revealed several relatively long $(>15 \mathrm{~km})$ lineaments east of the MPSSZ that appear to have been active during the late Cenozoic.

\section{GEOLOGIC AND SEISMOTECTONIC SETTING}

Sea-level changes during the Pliocene-Pleistocene have produced a series of terraces underlain by emergent marine landforms in the Atlantic Coastal Plain, including estuarine plains, back-barrier marshes, lagoonal deposits, and sandy barrier-island ridges (Colquhoun et al. 1991; Weems et al. 1997). The terraces are bounded on the seaward (southeast) side by eroded emergent littoral scarps, such as the Summerville scarp along the southeastern edge of the Penholoway terrace in the Summerville area (Fig. 1). The locations of the Penholoway terrace and the Summerville and other Pliocene-Pleistocene shorelines to the northeast were influ-enced by gentle uplift along the Woodstock fault (Marple and Talwani 2000).

Beneath the Coastal Plain, a coastward-thickening wedge of consolidated to poorly consolidated Cretaceous and Cenozoic sediments that is up to $1.1 \mathrm{~km}$ thick near Charleston (Weems and Lewis 2002) unconformably onlaps and buries early Mesozoic rift basins and pre-Mesozoic suspect and exotic terranes (Daniels et al. 1983). Four of the near surface formations, the Oligocene (30 $\mathrm{Ma})$ Ashley Formation, the middle Pleistocene (700-970 ka) Penholoway Formation, and the late Pleistocene Ten Mile Hill beds (200-240 ka) and Wando Formation (100 ka) (Weems et al. 1997), are briefly described here because they are integrated later with some of the geomorphic observations. The Ashley Formation consists of dense, erosion-resistant, weakly cemented, light-olive-brown, phosphatic and quartzose calcarenite that accumulated in an open-marine-shelf environment (Weems et al. 1997). The Penholoway Formation consists of sand, clayey sand, and clay deposited in shallow-marine to marginalmarine environments, the most notable of which is the barrier and back-barrier complex near Summerville (Weems et al. 1997) (Fig. 2). The Ten Mile Hill beds consist of poorly consolidated, easily eroded clays and clayey sands deposited in back-barrier and shallow shelf environments (Weems and Lemon 1993). The Wando Formation consists of poorly consolidated, easily eroded sand, clayey sand, and clay that were also deposited in back-barrier and shallow shelf-marsh environments (Weems and Lemon 1988, 1993).

Modern seismicity within the epicentral area of the 1886 Charleston earthquake is low level and clustered within the MPSSZ, the greatest concentration of which is located along the Ashley River northwest of Middleton Place (Fig. 1). Studies of focal mechanisms from the MPSSZ show a wide variety of fault-plane orientations and displacement sense (e.g., Shedlock 1988; Madabhushi and Talwani 1993). Hypocentral depths of these earthquakes range from 2 to $12 \mathrm{~km}$ (Madabhushi and Talwani 1993).

Previously mapped faults within the study area include the Ashley River, Berkeley, Charleston, Lincolnville, Sawmill Branch, Summerville, and Woodstock faults (Fig. 1). The largest fault is the $\sim 200$-km-long, NNE-SSW-oriented Woodstock fault that is associated with right-lateral strikeslip displacements (Marple and Talwani 2000). Southeast of the Woodstock fault is the NW-SE-oriented, SW-dipping 


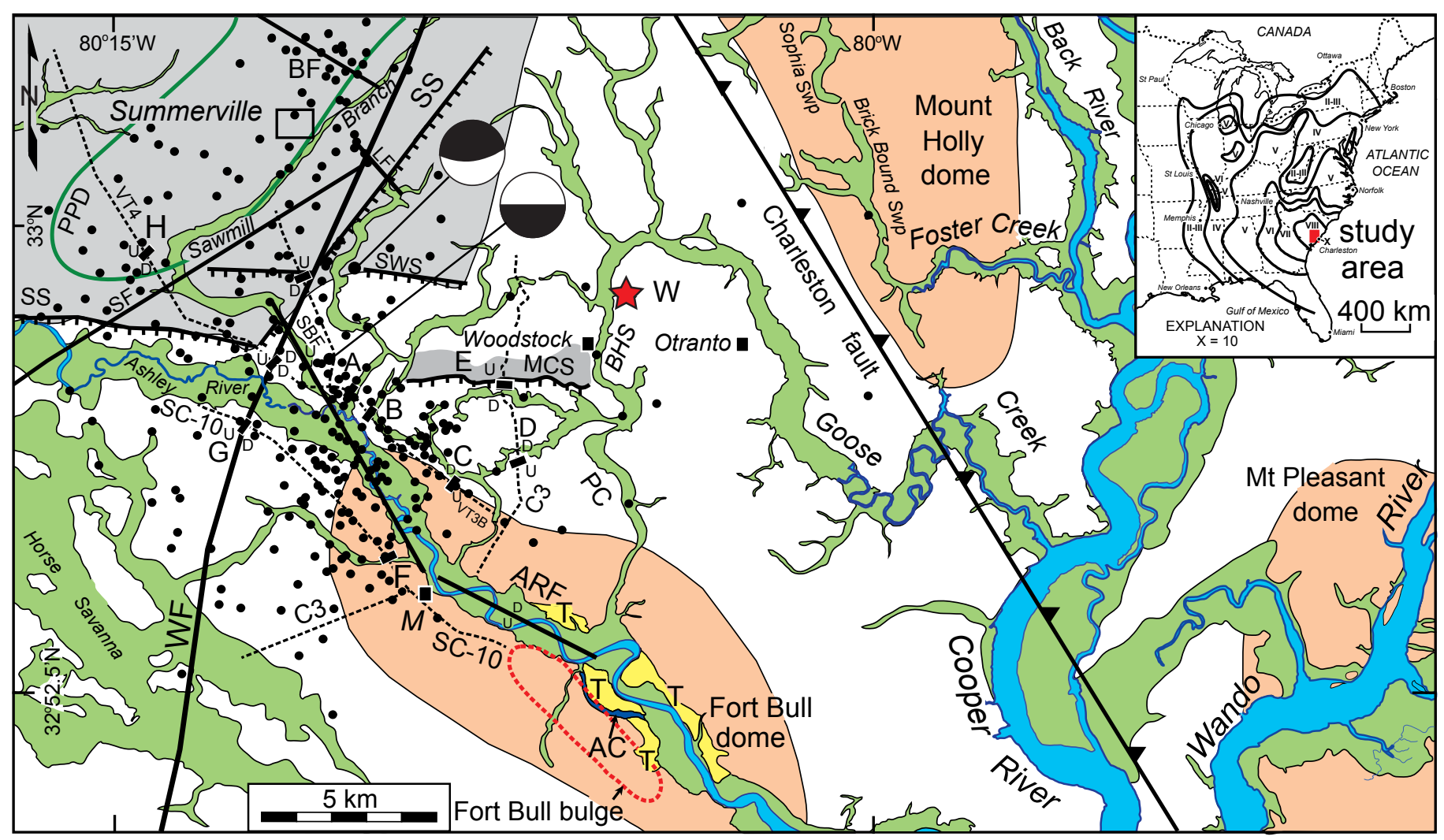

Figure 1. Study area showing seismicity (black dots) recorded between 1974 and 2019 (USGS 2019), structural domes (tan patterns), Fort Bull bulge (red dashed contour), pre-Pliocene dome (green contour labeled PPD) (Weems and Obermeier 1989), locations of seismic-reflection profiles (dashed lines) with interpreted faults at sites $\mathrm{A}-\mathrm{H}$, and topographically high area in the Summerville area (gray pattern). The two focal mechanisms are from Chapman et al. (2016). Index in upper right shows the location of the study area with the Modified Mercalli Intensity contours of the 1886 Charleston earthquake from Bollinger (1977) overlain. See Tables 1 and 2 for abbreviations of faults and scarps. PC is Popperdam Creek and BHS is Bluehouse Swamp. Yellow patterns labeled T are terraces along the Ashley River valley. Dark blue pattern labeled AC is an abandoned Ashley River channel. W (red star) is the Woodstock epicenter of the 1886 Charleston earthquake (Dutton 1890). $M$ is Middleton Place.

Ashley River reverse fault (Fig. 1) (Durá-Gómez and Talwani 2009). Southwest of Summerville is the NE-SWoriented, NW-dipping Summerville fault(Fig. 1)(Weems and Lewis 2002; Marple and Miller 2006). East of the MPSSZ is the NW-SE-oriented, $~ 50-\mathrm{km}$-long, high angle, NE-dipping reverse fault known as the Charleston fault that was interpreted based on borehole data (Colquhoun et al. 1983). The NW-SE-trending Sawmill Branch and Lincolnville faults (Fig. 1), as inferred from seismicity studies (e.g., DuráGómez and Talwani 2009), dip to the northeast and are associated mainly with reverse displacement. The NW-SEoriented Berkeley fault north of Summerville (Fig. 1) was interpreted by Marple and Miller (2006) based on seismicity. Its dip and style of displacement, however, are unknown. Table 1 shows abbreviations of faults used in the figures.

\section{Structural domes}

Several structural domes and areas of gentle warping have been mapped in the South Carolina Coastal Plain (Fig. 1).
One such area is the $200-\mathrm{km}$-long "zone of river anomalies" (ZRA) that is associated with gentle uplift along the Woodstock fault (Marple and Talwani 2000). Along the ZRA and between the Ashley River and Lake Moultrie is a topographically high area (Figs. 1 and 2) that Marple and Talwani $(1993,2000)$ postulated was from late Cenozoic uplift. The pre-Pliocene surface along this area is upwarped 10-15 m (Weems and Obermeier 1989) (Fig. 1).

The Fort Bull bulge and dome southeast of the MPSSZ are associated with late Pleistocene and/or Holocene uplift along the Ashley River fault (Weems and Lewis 2002) (Fig. 1). Northeast of the Fort Bull dome are the Mount Holly and Mount Pleasant domes that were produced by late Cenozoic uplift along the northeastern side of the Charleston fault (Weems and Lewis 2002) (Fig. 1). Other domes mapped in the Charleston region are summarized in Weems and Lewis (2002). 


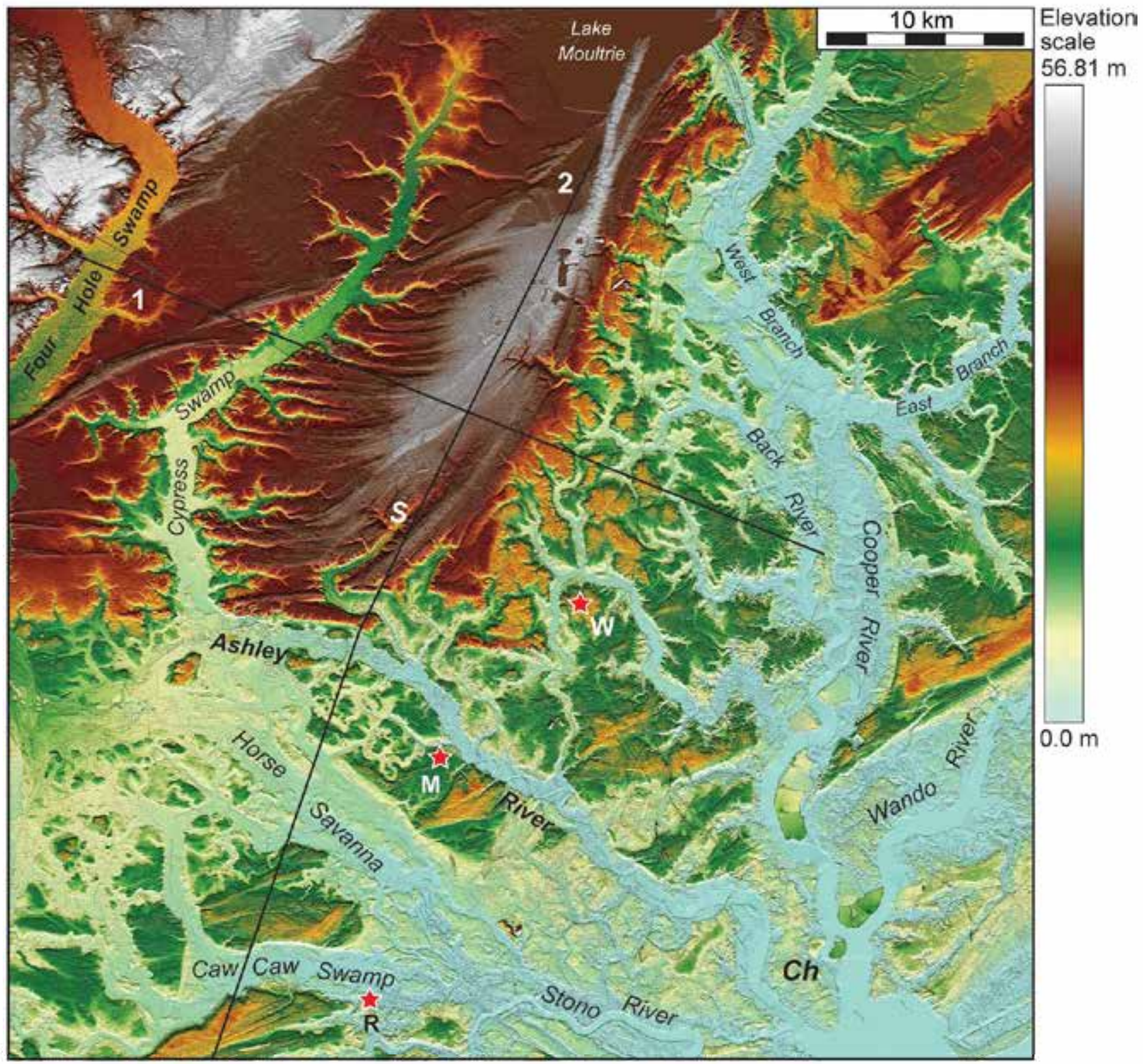

Figure 2. Color LiDAR image of the Charleston, South Carolina, region. Illumination angle is $180^{\circ}$. Red stars are the three epicenters of the 1886 Charleston earthquake near Woodstock (W), Rantowles (R), and Middleton Place (M) (McKinley 1887; Dutton 1890). Black lines are elevation profiles shown in Figure 5. Ch and S are Charleston and Summerville.

\section{METHODS AND DATA USED}

\section{LiDAR data}

The LiDAR data that we used for this study were acquired in 2009 from the South Carolina Department of Natural Resources (DNR 2019). Digital elevation models (DEMs) were derived from the ground surface classified point cloud and converted into a 10 foot $(\sim 3 \mathrm{~m})$ spatial resolution raster layer. The DEM represents the average surface elevation for each 10 foot raster grid. We used the Hillshade tool of ArcGIS to generate shaded relief images from the DEM data using various illumination azimuths, an elevation angle of $25^{\circ}$, and a vertical exaggeration of $10 \times$. Color relief images were then generated using a color scheme based on elevations of the terrain. Basic contrast enhancement routines of Adobe Photoshop were used to digitally enhance the LiDAR images. Low contrast images were enhanced further using the intensity-hue-saturation (IHS) routine of Adobe Photoshop. We were not able to generate elevation scales for these images because the IHS enhancement significantly changed their color schemes. The LiDAR data were also used to construct detailed topographic profiles across selected features to quantify elevation changes across them. Lineaments were compared to topographic and geologic maps at various scales to ensure that they are not associated with man-made or nontectonic landforms, such as streams that have formed between Pleistocene beach ridges. Geologic and topographic 
Table 1. Fault name abbreviations.

$$
\begin{aligned}
& \text { ARF - Ashley River fault } \\
& \text { BF - Berkeley fault } \\
& \text { CF - Charleston fault } \\
& \text { LF - Lincolnville fault } \\
& \text { SBF - Sawmill Branch fault } \\
& \text { SF - Summerville fault } \\
& \text { WF - Woodstock fault }
\end{aligned}
$$

maps were also used to distinguish between potential fault scarps and linear cutbanks along the edges of stream valleys. The lineaments were also overlain with previously acquired seismic-reflection profiles, aeromagnetic data, and instrumentally recorded earthquakes to determine if they are fault-related and possibly active (Fig. 1). Some of the LiDAR lineaments were then field checked. Table 2 shows abbreviations of lineaments and scarps used in the figures.

\section{Seismic-reflection profiles}

The previously acquired seismic-reflection profiles that we used to search for evidence of faults along some of the LiDAR lineaments in the study area are Consortium for Continental Reflection Profiling (COCORP) line C3, United States Geological Survey (USGS) line SC-10, and Virginia Polytechnic Institute (Virginia Tech) lines VT3B and VT4 (Fig. 1). Sites A-H in Figure 1 show the locations of faults offsetting Cretaceous, Paleogene, and Neogene strata along

Table 2. Abbreviations for names of lineaments and scarps.

$$
\begin{aligned}
& \text { ARL - Ashley River lineament } \\
& \text { BHL - Boone Hill lineament } \\
& \text { CHL - Canterhill lineament } \\
& \text { CL - Coosaw Creek lineament } \\
& \text { DL - Dawson lineament } \\
& \text { DPL - Deer Park lineament } \\
& \text { EL - Eagle Creek lineament } \\
& \text { FQL - French Quarter lineament zone } \\
& \text { LBL - Lambs lineament } \\
& \text { MCS - McChune scarp } \\
& \text { MGL - Magnolia Gardens lineament } \\
& \text { MHL - Mount Holly lineament } \\
& \text { MPL - Middleton Place lineament } \\
& \text { SS - Summerville scarp } \\
& \text { SWS - Summerwood scarp } \\
& \text { WL - Waring lineament }
\end{aligned}
$$

these profiles. Line C3 is a 24 -fold Vibroseis seismic-reflection profile collected in 1978 using 5 vibrator trucks and a receiver group spacing of $67 \mathrm{~m}$ (Schilt et al. 1983). It was acquired in two parts with a $\sim 3-\mathrm{km}$-wide gap across the Ashley River valley. Schilt et al. (1983) interpreted a SW-side-up fault within this gap. They also interpreted a small fault-bounded graben along this profile $\sim 5 \mathrm{~km}$ north of the Ashley River valley (Fig. 1, site E). This graben extends up dip into the Cretaceous strata with a small, net $\mathrm{N}$-side-up displacement across this structure (figure 10 of Schilt et al. 1983).

USGS seismic-reflection profile SC-10 is a 12-fold Vibroseis profile that was collected in 1979 along the south side of the Ashley River valley (Fig. 1) using 3 vibrator trucks and a receiver group spacing of $60 \mathrm{~m}$ (Hamilton et al. 1983). This profile revealed two faults. The fault toward the west end of the line (Fig. 1, site G) offsets Cretaceous and Cenozoic strata up to the west. Marple and Talwani (2000) interpreted this fault to be part of the Woodstock fault. A second SEside-up fault occurs to the southeast that offsets Cretaceous and Cenozoic strata (Hamilton et al. 1983). This fault coincides with the Middleton Place lineament of this study (Fig. 1, site F).

Seismic-reflection profiles VT3B and VT4 were collected in 1981 across the MPSSZ (Fig. 1) by Virginia Tech in collaboration with the USGS using the RGL Vibroseis system (Chapman and Beale 2008). These 24-fold data were collected with a single vibrator truck and a receiver group spacing of $35 \mathrm{~m}$ (Chapman and Beale 2008). Several of the faults interpreted along these two lines offset Cretaceous and Cenozoic strata (Chapman and Beale 2010).

\section{LIDAR OBSERVATIONS}

The LiDAR images of the MPSSZ and surrounding area revealed several lineaments oriented in many directions, the greatest concentration of which occurs east of the bend in the Woodstock fault (Fig. 3b). Selected lineaments and other geomorphic features are discussed further in the following sections.

\section{Deer Park lineament}

Crossing the community of Deer Park is a subtle, E-W-oriented linear depression, herein named the Deer Park lineament, that coincides approximately with the Woodstock epicenter (Figs. 3b and 4). The Deer Park lineament between Bluehouse Swamp and Goose Creek valley is defined by a subtle 0.5 - to 1.5 -m-deep depression and a gentle 0.5 - to 1-m-high, south-facing scarp (Figs. 4 and 5, profiles 3-6). The depression along this part of the lineament deepens into short streams that cut into the valley walls of the Bluehouse and Goose Creek swamps. The Deer Park lineament continues to the west along E-W-oriented segments of Coosaw and Eagle creeks and Sawmill Branch (Fig. 3). East of Goose Creek valley, the Deer Park lineament is collinear with the E-W-oriented segment of Foster Creek valley (Fig. 3). 

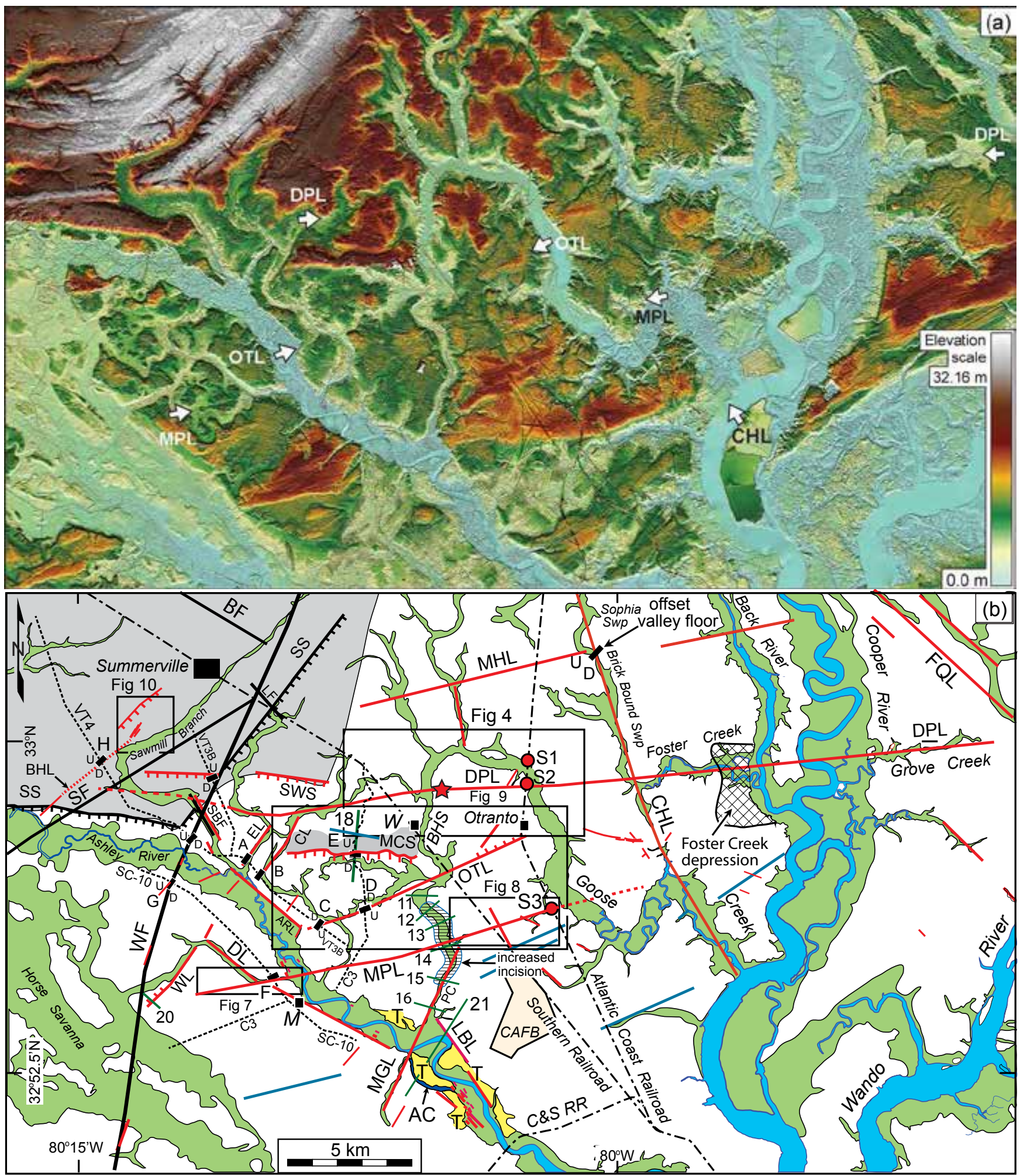

Figure 3. (a) Color LiDAR image of the MPSSZ. Illumination azimuth is $180^{\circ}$. CHL, DPL, MPL, and OTL are the Canterhill, Deer Park, Middleton Place, and Otranto lineaments (between arrows). (b) Map for image (a). CAFB is the Charleston Air Force Base. See Tables 1 and 2 for abbreviations of faults, lineaments and scarps. Blue lines are examples of lineaments associated with stream erosion along Pleistocene barrier island sediments. M is Middleton Place, W is Woodstock. PC is Popperdam Creek and BHS is Bluehouse Swamp. Woodstock epicenter (star) is from Dutton (1890). PC is Popperdam Creek. Green lines are elevation profiles shown in Figure 5. Yellow patterns labeled T are terraces along the Ashley River valley. Dark blue pattern labeled AC is an abandoned Ashley River channel. C\&S RR (dashed line) is the Charleston \& Savannah Railway. Sites S1, S2, and S3 are explained in the text. 
Near the mouth of Foster Creek and along the trend of the Deer Park lineament is an unusual, $2 \times 2.5-\mathrm{km}$-size, 7 - to 8 -m-deep, 3-sided depression bounded by relatively steep scarps intersecting at $\sim 90^{\circ}$ and stepping down from the back-barrier deposits of the Ten Mile Hill beds to those of the Wando Formation (Figs. 3 and 6a). The near right angles between the scarps cannot be explained easily by a laterally migrating stream or estuary wave action, which led Weems and Lemon (1993) to conclude that the depression is a tectonic feature younger than the Ten Mile Hill beds (200 ka, Weems and Lemon 1993). We have named this feature the Foster Creek depression.

East of the Foster Creek depression and the Cooper River, the Deer Park lineament is collinear with the Grove and Little Johnson creeks (Fig. 3). A 2-km-long eastward-plunging anticlinal fold in the pre-Quaternary surface is located approximately $4 \mathrm{~km}$ east of Little Johnson Creek (Weems and Lemon 1989, 1993).

\section{Middleton Place lineament}

The $\sim 17-\mathrm{km}$-long Middleton Place lineament extends ENE-WSW across the southern end of the MPSSZ to the Goose Creek valley (Fig. 3). Its southwestern end is characterized by an $\sim 180$-m-wide zone of 1 - to $1.5-\mathrm{m}$-deep, $\sim 30$-m-wide linear depressions that converges with left-stepping en échelon stream segments that drain into the Ashley River to the east (Figs. 5 and 7, profile 7). Within these depressions are linear, $\sim 1$-m-wide, water-filled depressions up to $350 \mathrm{~m}$ long and only a few $\mathrm{cms}$ deep in most places that are developed within late Pleistocene to Holocene swamp sediments (Fig. 7c). East-northeast of this location, the Middleton Place lineament coincides with a steeply dipping, SEside-up fault interpreted from seismic-reflection profile SC10 (Fig. 7b). To the east-northeast, the Popperdam Creek is more deeply incised $(\sim 2 \mathrm{~m})$ and its floodplain is terrace-like, rather than swampy, where it intersects the lineament (Figs. $3 \mathrm{~b}$ and 5, profiles 11-16). The valley floor is $1-2 \mathrm{~m}$ higher near the lineament than that upstream and downstream (Fig. 5, profiles 13 and 14). A longitudinal profile along the valley floor is convex upward at least $2 \mathrm{~m}$ (Fig. 5, profile 17). The lower valley below the lineament, however, is covered in places with 2-3 m of phosphate spoil from mining of phosphate during the last 120 years (Fig. 5, profile 17) (Weems and Lemon 1988), thus making interpretation of incision along the lower valley difficult. East of Popperdam Creek, the Middleton Place lineament is characterized by a subtle, 2- to 6-m-deep linear depression where it crosses the community of Ashley Heights (Fig. 5, profiles 8 and 9) and a sharp $\sim 90^{\circ}$ bend in a small tributary of Goose Creek (Fig. 8).

\section{Otranto lineament}

The $~ 10-\mathrm{km}$-long, NE-SW-trending Otranto lineament extends from the eastern side of the MPSSZ to just south of Otranto (Fig. 3). It is defined by a 3- to 7-m-deep, 5-kmlong linear depression (Fig. 5, profile 10) and a 1.5-km-wide, right-stepping deflection of the Bluehouse Swamp (Fig. 9). Along this deflection, the Bluehouse Swamp and Popperdam Creek valley collectively form an S-shaped curve (Fig. 9). Near Otranto, the Otranto lineament coincides with a 2.5-km-long, north-facing, 3-m-high gentle scarp. At its southwestern end, the Otranto lineament coincides with two buried, SW-dipping, SW-side-up faults on seismicreflection profiles VT3B and C3 that offset Cretaceous and Cenozoic strata (figures 2 and 5 of Chapman and Beale 2010) (Fig. 9b).

\section{McChune and Summerwood scarps}

Just north of the Otranto lineament and extending beyond the topographically high area near Summerville (Fig. 3) is the 10- to $12-\mathrm{m}$-high, south-facing, E-W-oriented, $\sim 5-\mathrm{km}$ long McChune scarp and $\sim 1-\mathrm{km}$-wide McChune ridge (Fig. 5, profile 18). The 2- to 4-m-deep McChune Branch of the Bluehouse Swamp coincides with the base of the scarp. The scarp also coincides with a small fault-bounded graben along seismic-reflection profile C3 (figure 10 of Schilt et al. 1983) (Fig. 9b). The Cenozoic strata display a small net $\mathrm{N}$-side-up displacement across this structure. The McChune scarp is collinear with the E-W-oriented part of the Summerville littoral scarp to the west where the terrain drops 8 to $10 \mathrm{~m}$ to the south (Figs. 3 and 5, profile 2). These two scarps are separated by a $\sim 4$-km-wide gap where the Woodstock fault and the NE-SW-oriented Coosaw Creek and Eagle Creek lineaments cross the trend of these 2 scarps (Fig. 3b). The McChune ridge and scarp end abruptly to the west along the Coosaw Creek lineament (Fig. 3b). The 3-km-long, south-facing, E-W-trending Summerwood scarp is northwest of the McChune scarp (Fig. 3). E-Woriented focal mechanisms coincide with the trends of the McChune and Summerwood scarps (Fig. 1).

\section{Mount Holly lineament}

The 17-km-long, NE-SW-oriented Mount Holly lineament east of Summerville (Fig. 3b) is defined mainly by a discontinuous series of linear depressions. A 200-m-wide portion of the valley floor is $\sim 3.5 \mathrm{~m}$ higher than along the Brick Bound Swamp to the south and the Sophia Swamp to the north where the lineament intersects the Canterhill lineament, thus forming a drainage divide between these two swamps (Fig. 5, profiles 22-25). The valley floor along these and other swamps along this trend are concave upward (Fig. 5, profile 22). The Wando Formation underlies the $2.5-\mathrm{km}$ reach of the Sophia Swamp along and north of the topographically higher part of the valley (Weems and Lemon 1984a) (Fig. 5, profile 22).

\section{Boone Hill lineament}

Approximately $7 \mathrm{~km}$ southwest of Summerville are two NE-SW-oriented linear depressions that collectively form the Boone Hill lineament (Fig. 3). Figure 10 shows an enlarged 

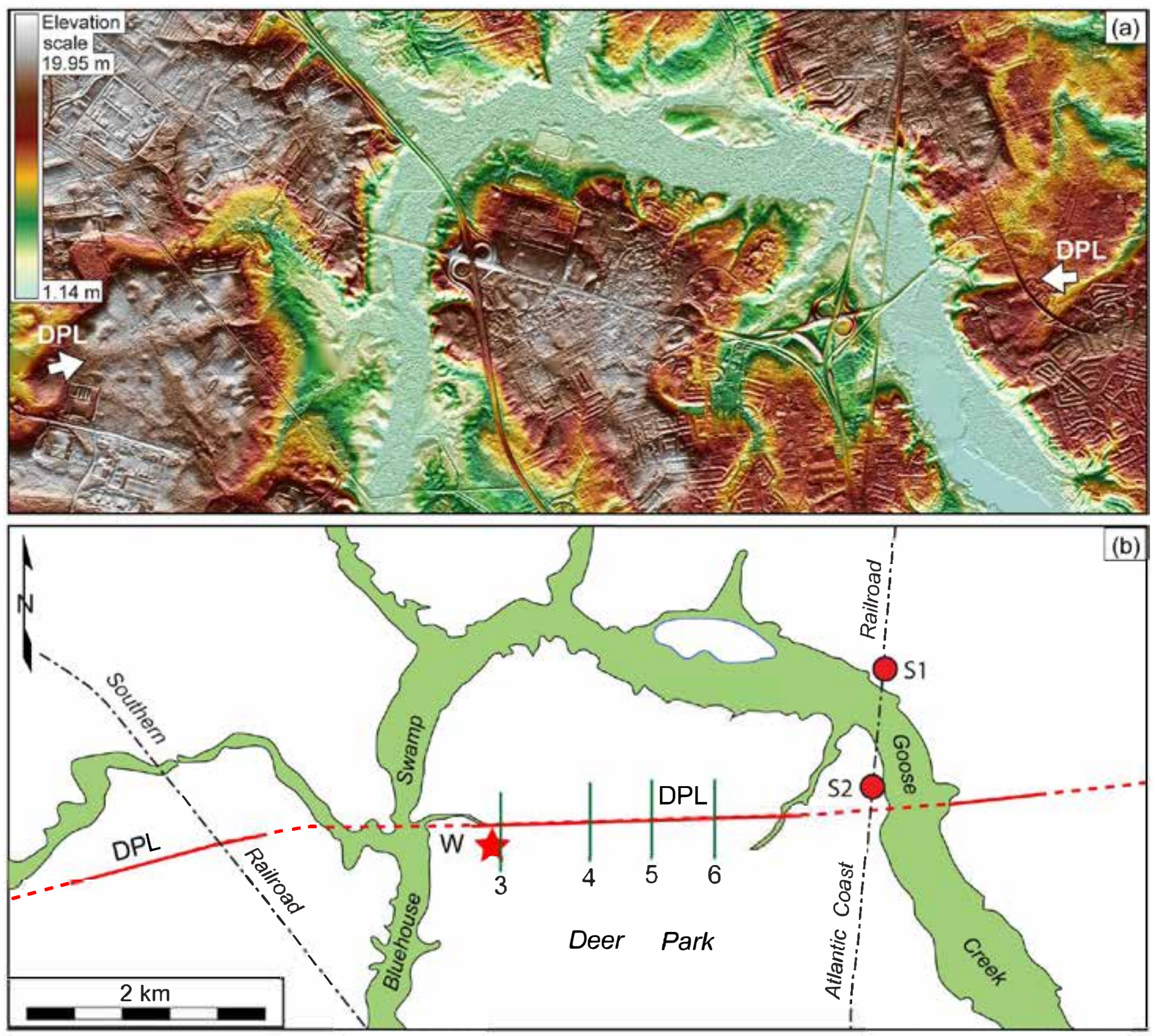

Figure 4. (a) Color LiDAR image showing the Deer Park lineament (DPL) between arrows. Illumination azimuth is $180^{\circ}$. (b) Map for image (a). Green lines are elevation profiles shown in Figure 5. Sites S1 and S2 are explained in the text. W (star) is the Woodstock epicenter.

LiDAR image of the Boone Hill lineament where it intersects the Sawmill Branch valley. Here the lineament is defined by a $\sim 200$-m-wide, $\sim 700$-m-long zone of 1 - to 2 -m deep linear depressions within a small valley (Fig. 5, profile 19) that converges with the Sawmill Branch valley. Approximately $3 \mathrm{~km}$ to the southwest, the Boone Hill lineament is defined by a $\sim 2.3-\mathrm{km}$-long linear depression that obliquely crosses the Summerville scarp (Fig. 3b). The Boone Hill lineament is semi-parallel to the Summerville fault to the southeast and lies near a buried, NW-side-up fault on seismicreflection profile VT-4 (Fig. 3b) that offsets Cretaceous and Cenozoic strata (figure 7 of Chapman and Beale 2010).

\section{Other lineaments}

The 4-km-long, NW-SE-oriented Ashley River lineament is formed by a relatively straight segment of the Ashley River's northern valley wall where it crosses the MPSSZ (Fig. 3 ). The Oligocene Ashley Formation is exposed along the base of this part of the northern valley wall but not along the corresponding south valley wall (Weems and Lemon $1984 b$ ), suggesting $\mathrm{N}$-side-up displacement along this lineament. The lineament ends abruptly to the southeast where it intersects the southwest projection of the Otranto lineament (Fig. 3b). 

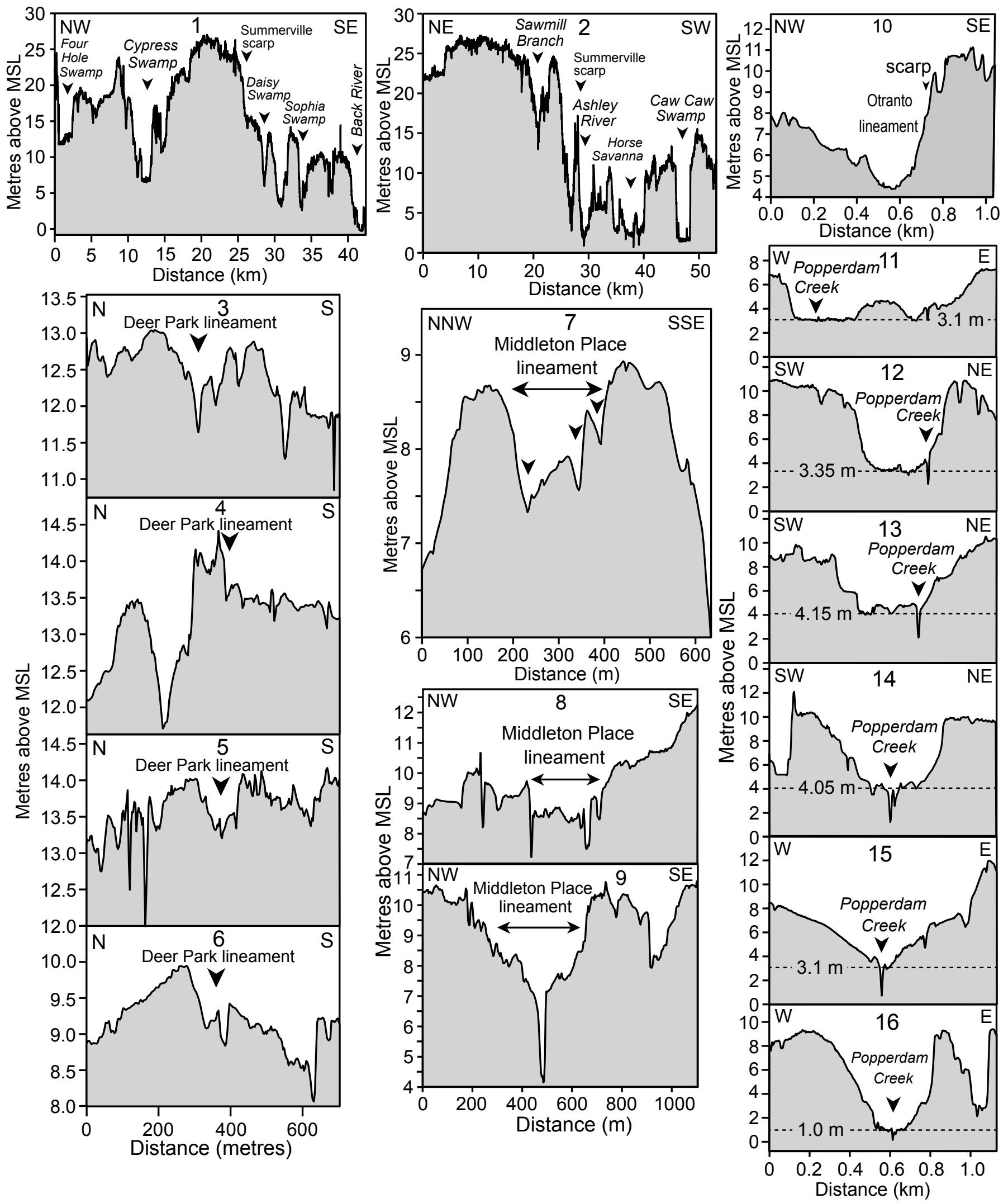

Figure 5. (above and next two pages) Elevation profiles constructed across various scarps and lineaments and Popperdam Creek in the study area. Horizontal dashed lines in profiles 11-16 are elevations of the Popperdam Creek valley floor. Label 'ps' on profile 17 refers to areas with phosphate spoils. The other profiles are described in the text. Location of the index map for profiles 22-25 is shown in Figure 14. Profiles 22-25 are along and across the Brick Bound and Sophia swamps near the Mount Holly lineament. 

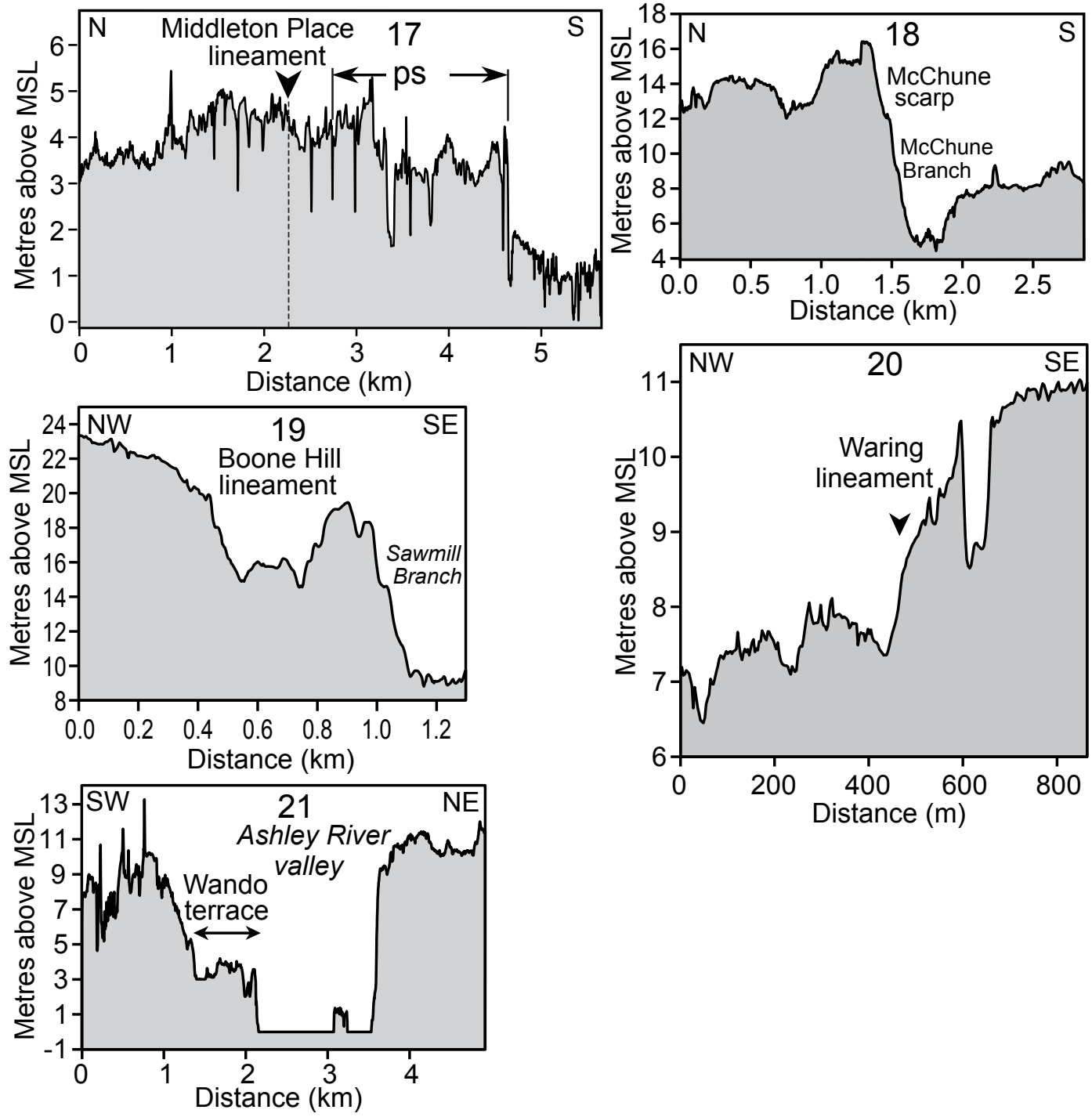

Figure 5. (continued)

The 4-km-long, NE-SW-oriented Waring lineament crosses the southern part of the MPSSZ southwest of the Ashley River lineament (Fig. 3). This lineament is defined by a straight segment of a tributary that drains into the Ashley River and a gentle, 1- to 2-m-high, 800-m-long, NW-facing scarp to the southwest (Figs. 3 and 5, profile 20). The base of the scarp coincides with a linear, 20-50-m-wide swampy depression. Northeast of and slightly off-trend from the Waring lineament is the $\sim 3-\mathrm{km}$-long Coosaw Creek lineament that is formed mainly by a relatively straight reach of Coosaw Creek (Fig. 3). Approximately $1 \mathrm{~km}$ west of and parallel to the Coosaw Creek lineament is the $\sim 2-\mathrm{km}$-long NNE-SSW-oriented Eagle Creek lineament that is defined by a straight segment of Eagle Creek (Fig. 3). The Coosaw and Eagle creek lineaments coincide with small buried faults at sites A and B of Figure $3 \mathrm{~b}$ (figure 4 of Chapman and Beale 2008).

The 20-km-long Canterhill lineament east of the MPSSZ is formed primarily by the alignment of the Brick Bound, Sophia, and Canterhill swamps and the NNW-SSE-oriented reaches of the Foster and Goose Creek valleys (Fig. 11). It parallels the nearby Charleston fault (Fig. 1). A prominent, $\sim 20$-km-long, 2- to 3-km-wide zone of NW-SE-oriented lineaments, northeast of the Canterhill lineament and collectively named the French Quarter Creek lineament zone, is primarily formed by the alignment of the West Branch of the Cooper River valley and other linear depressions to the northwest with the French Quarter Creek valley and Chipper Swamp to the southeast (Fig. 11). Unlike most streams crossing the Coastal Plain, French Quarter Creek flows northwest away from the coast before emptying into the Cooper River. Other lineaments were interpreted across the study area (Fig. 3b), but are not described here for the sake of brevity.

Figure 5. (concluded next page) 

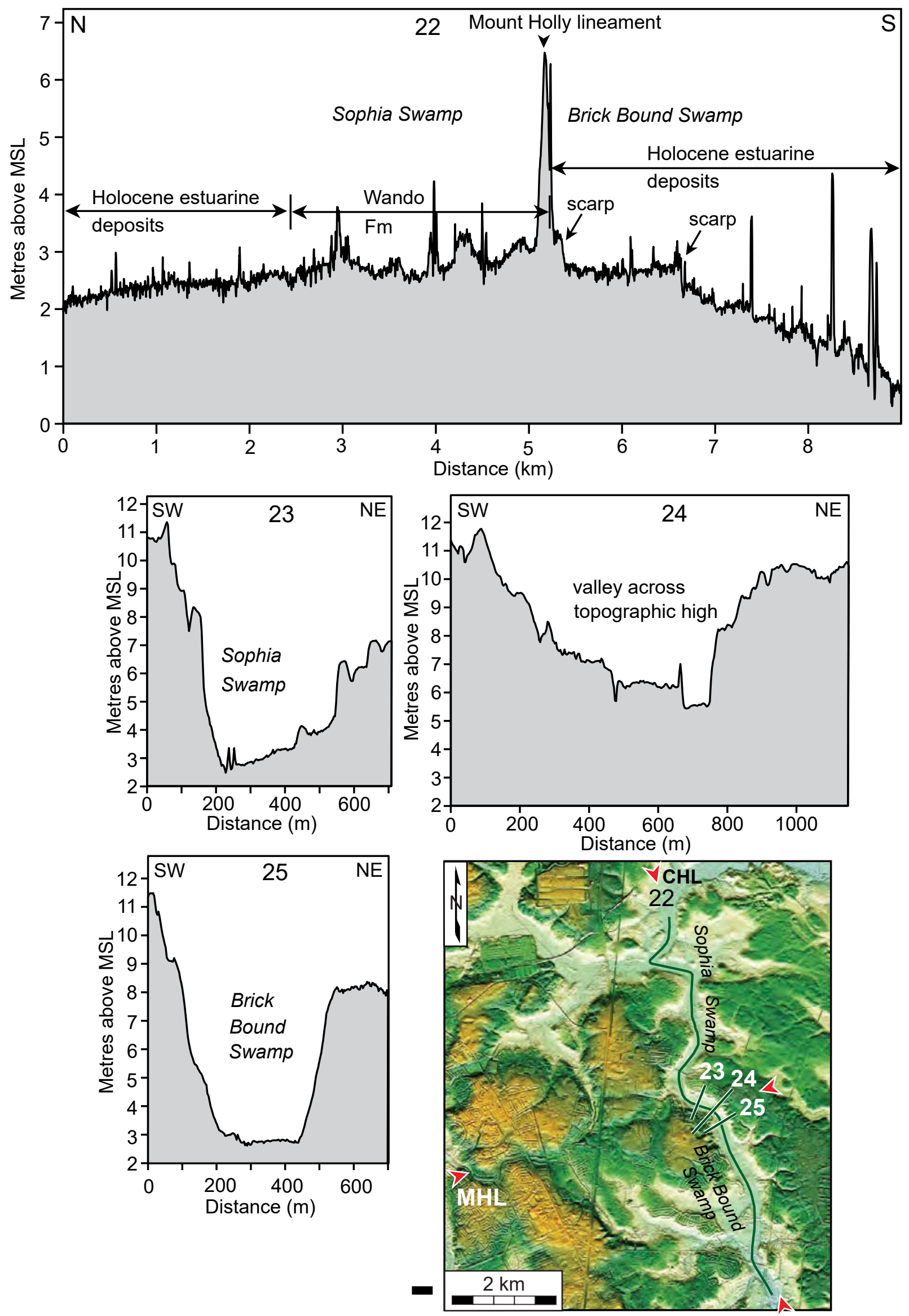

index map for profiles 22-25 

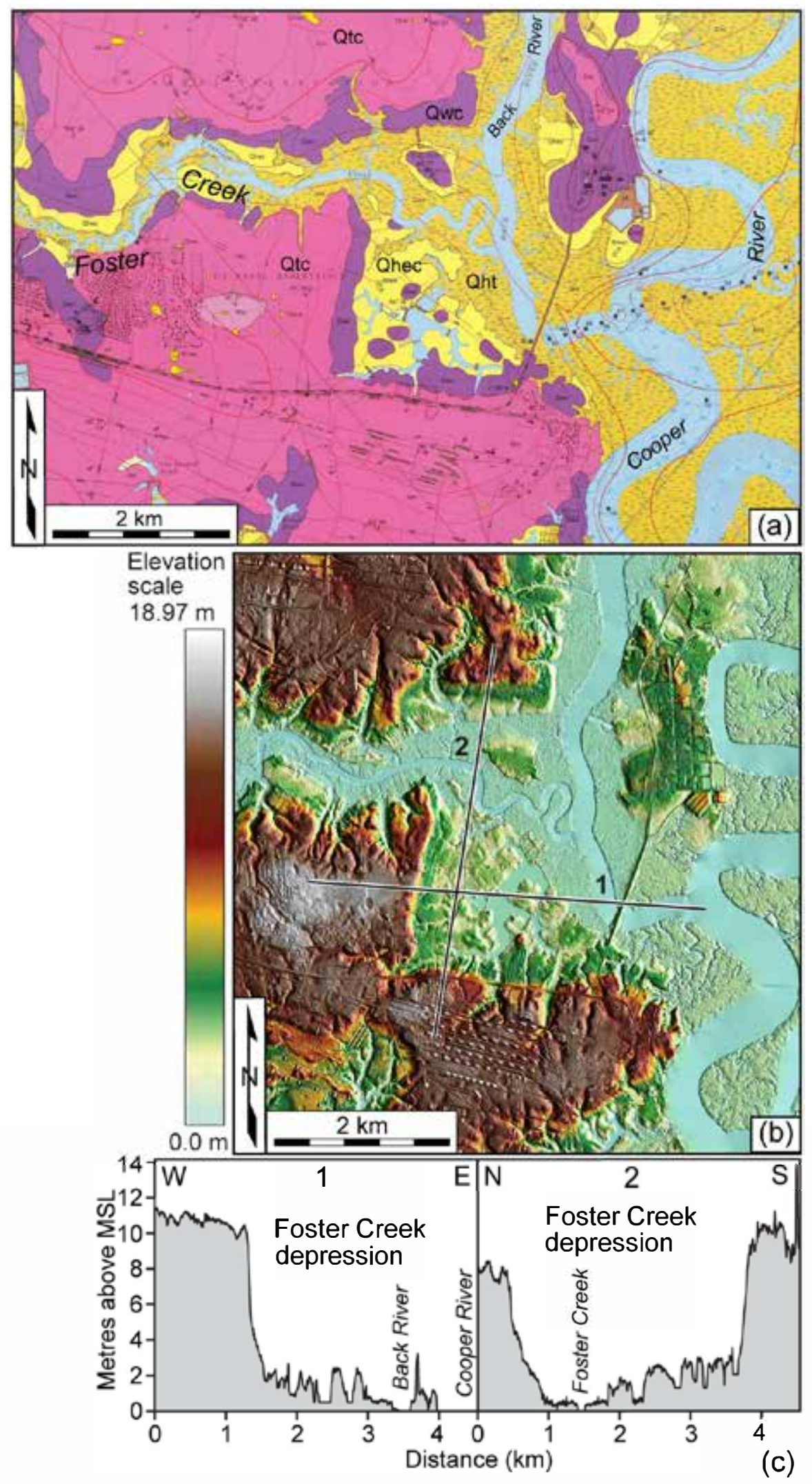

Figure 6. (a) Portion of surficial geologic map taken from Weems and Lemon (1993) showing the Foster Creek depression. Geologic units: Qht - Holocene tidal marsh deposits, Qhec - Holocene estuarine deposits, Qtc - Ten Mile Hill sediments, Qwc - Wando Formation (see text for descriptions). (b) LiDAR image of the Foster Creek depression. Illumination azimuth is $80^{\circ}$. Location of image is shown in Figure 14. (c) Elevation profiles 1 and 2 (locations on b) across the Foster Creek depression. 

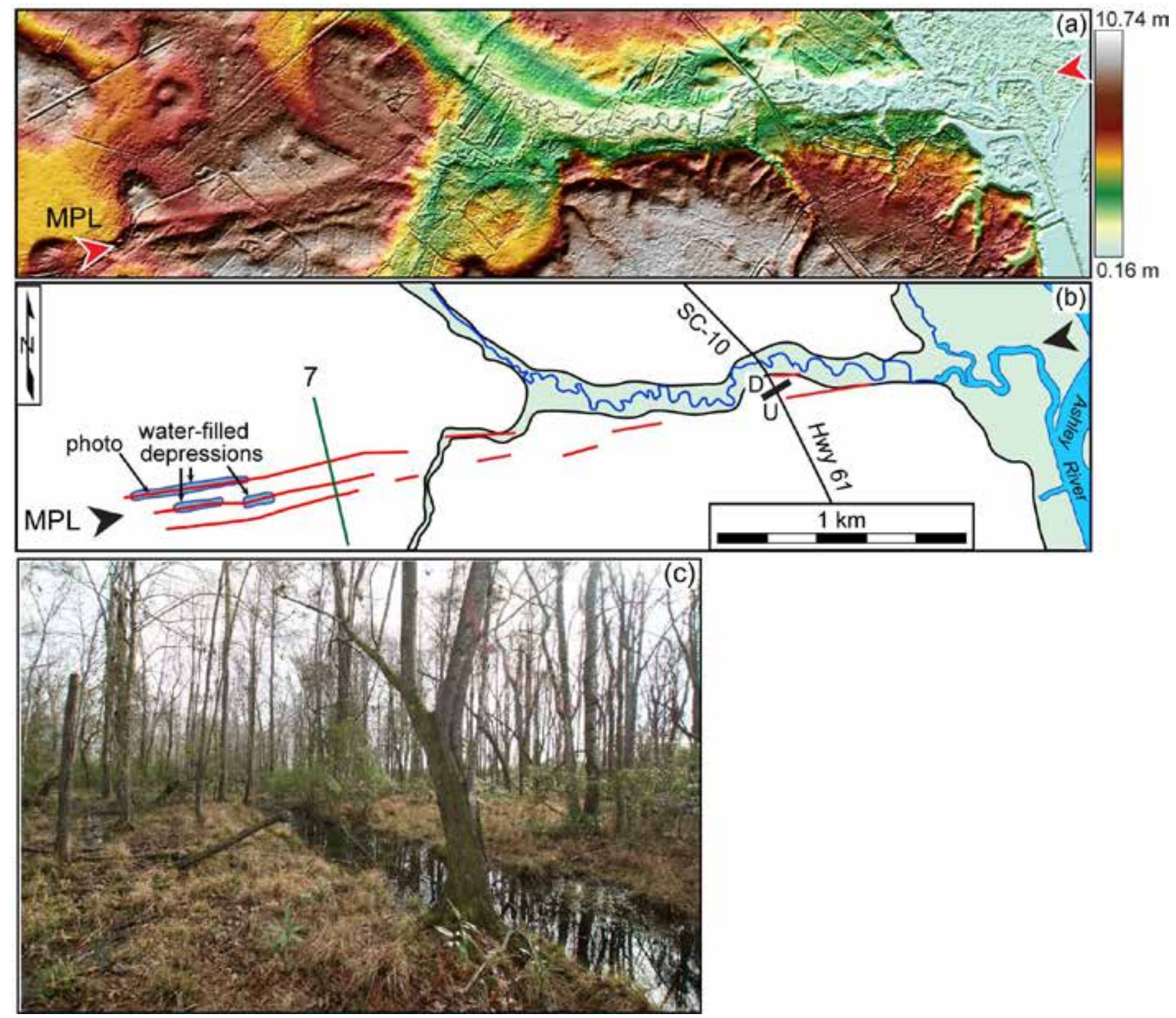

Figure 7. (a) Color LiDAR image of the Middleton Place lineament (MPL, between opposing arrows). Illumination azimuth is $200^{\circ}$. (b) Map for image (a). Line labeled SC-10 is a seismic-reflection line from Hamilton et al. (1983). Green line is an elevation profile shown in Figure 5. (c) Photo (view toward east-northeast) of a shallow, water-filled linear depression taken 16 January 2020 along one of the linear valleys near the southwestern end of the MPL.

\section{Dextral offset of a middle Pleistocene beach ridge and other geomorphic features north of Summerville}

Approximately $8 \mathrm{~km}$ northeast of Summerville, a middle Pleistocene beach ridge displays $\sim 350$ - $\mathrm{m}$ of dextral offset where it crosses the Woodstock fault at a low angle (Marple and Hurd 2020) (Fig. 12). Approximately $1.5 \mathrm{~km}$ of the ridge appears to have been eroded away at this offset (Fig. 13, profile 27). Between Lake Moultrie and the Ashley River, a change in color on the LiDAR image from dark brown (lower elevations) to off-white (higher elevations) indicates that the numerous beach ridges across the Penholoway terrace are 10-15 $\mathrm{m}$ higher near the trend of the Woodstock fault (Figs.
$2,12 \mathrm{~b}$, and 13 , profile 26 ). This area of elevated beach ridges coincides approximately with the upwarped pre-Pliocene surface of Weems and Obermeier (1989) (Fig. 1). Numerous 30- to 100-m-wide, shallow, 0.7-1.5 m deep circular depressions also exist across the Penholoway terrace and the rest of the study area (e.g., Figs. 12 and 13, profile 30).

\section{DISCUSSION}

\section{Origin of the LiDAR lineaments}

Because some of the lineaments coincide with faults interpreted from the seismic-reflection profiles (Figs. $3 \mathrm{~b}$ and 


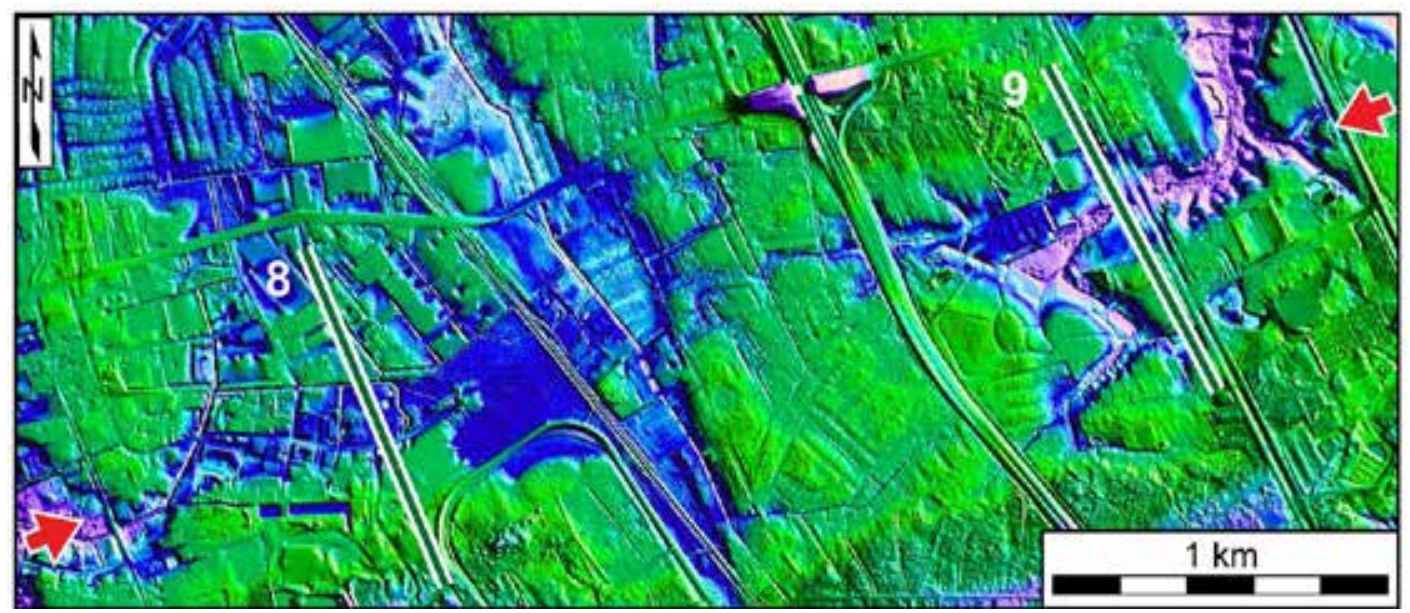

Figure 8. IHS-enhanced LiDAR image showing a linear depression (between arrows) along the trend of the Middleton Place lineament. Illumination azimuth is $60^{\circ}$. Green lines are elevation profiles shown in Figure 5. Colors represent depths ranging from blue for the lowest elevations to green for the highest elevations.

7b), such as the Middleton Place and Otranto lineaments, it is more likely that they formed from increased erosion along brittle faults that reach the surface. Such a process could explain why many of the lineaments coincide with linear stream valleys (Figs. 3 and 11). Other evidence supports the association of the lineaments with surface faults. The Middleton Gardens lineament (Fig. 3), for example, occurs along the northwestern edge of a buried graben beneath this part of the Ashley River valley (Lennon 1986). Another mechanism that has produced a few lineaments is erosion along linear Pleistocene barrier island deposits, like the blue lineaments in Figure 3b, that formed along Pleistocene beach ridges.

\section{Origin of the McChune and Summerwood scarps}

Rhea (1989) proposed that the area north and west of the Summerville scarp and east of Four Hole Swamp (Fig. 1) is associated with uplift. The alignment of the E-W-oriented part of the Summerville scarp with the McChune scarp (Fig. $3 \mathrm{~b}$ ), the coincidence of the small fault along seismic-reflection profile $\mathrm{C} 3$ with the McChune scarp (Fig. 3b), and the E-W-oriented focal mechanisms along this trend (e.g., Fig. 1) suggest that these two scarps and higher terrain north of the E-W-oriented part of the Summerville scarp may be from $\mathrm{N}$-side-up Quaternary displacements along a buried $\mathrm{E}-\mathrm{W}$-oriented fault beneath these two scarps. The greater thickness of the Oligocene Ashley Formation along the northern wall of this part of the Ashley River valley (Weems and Lemon 1984b) further supports uplift north of the Summerville scarp. Moreover, the McChune scarp extends eastward beyond the southern edge of the topographically higher terrain near Summerville (Figs. 2 and $3 \mathrm{~b}$ ). Therefore, the higher terrain north of the Ashley River is likely from gentle uplift that caused the Penholoway terrace and Summerville scarp to develop in their present location, as proposed by Marple and Talwani (2000). The gap between these two scarps is likely from increased erosion along faults associated with the NNE-SSW-oriented Coosaw and Eagle creek lineaments that cross the gap (Fig. 3b). The E-Woriented focal mechanisms that coincide with the trend of the Summerwood scarp to the north (e.g., Fig. 1) suggest that it too could be fault related.

\section{Possible association of the lineaments with the bend in the Woodstock fault}

Most of the LiDAR lineaments occur east of the bend in the Woodstock fault where they cross the greatest concentration of seismicity (Fig. 14). This spatial association supports the hypothesis of Marple and Miller (2006) that the interpreted faults east of the bend formed to compensate for the increased compression and change in volume produced by dextral motion along the bend in the Woodstock fault. The clustered seismicity east of the fault bend reflects the anomalously high amount of stress expected at this location. Secondary faults are common along restraining bends in strike-slip faults (e.g., Cunningham and Mann 2007 and references therein). Furthermore, fault bends and associated cross-faults can produce large earthquakes, such as the $\mathrm{M}$ 7.91857 Fort Tejon, Ms 7.1 1989 Loma Prieta, and Ms 7.5 1992 Landers earthquakes in California, USA (Schwartz et al. 1990; Sieh and Williams 1990; Du and Aydin 1996), and the $M_{\mathrm{s}} 1976$ Tangshan, China, earthquake (King and Nábělek 1985).

\section{Cause of the 1886 Charleston earthquake}

Certain observations suggest that the main shock of the 1886 Charleston earthquake may have occurred along a fault associated with the Deer Creek lineament. First, the Deer Creek lineament coincides approximately with the Woodstock epicenter (Fig. 4b). Secondly, the reversal of compressional thrusting of the railway tracks near the lineament east 

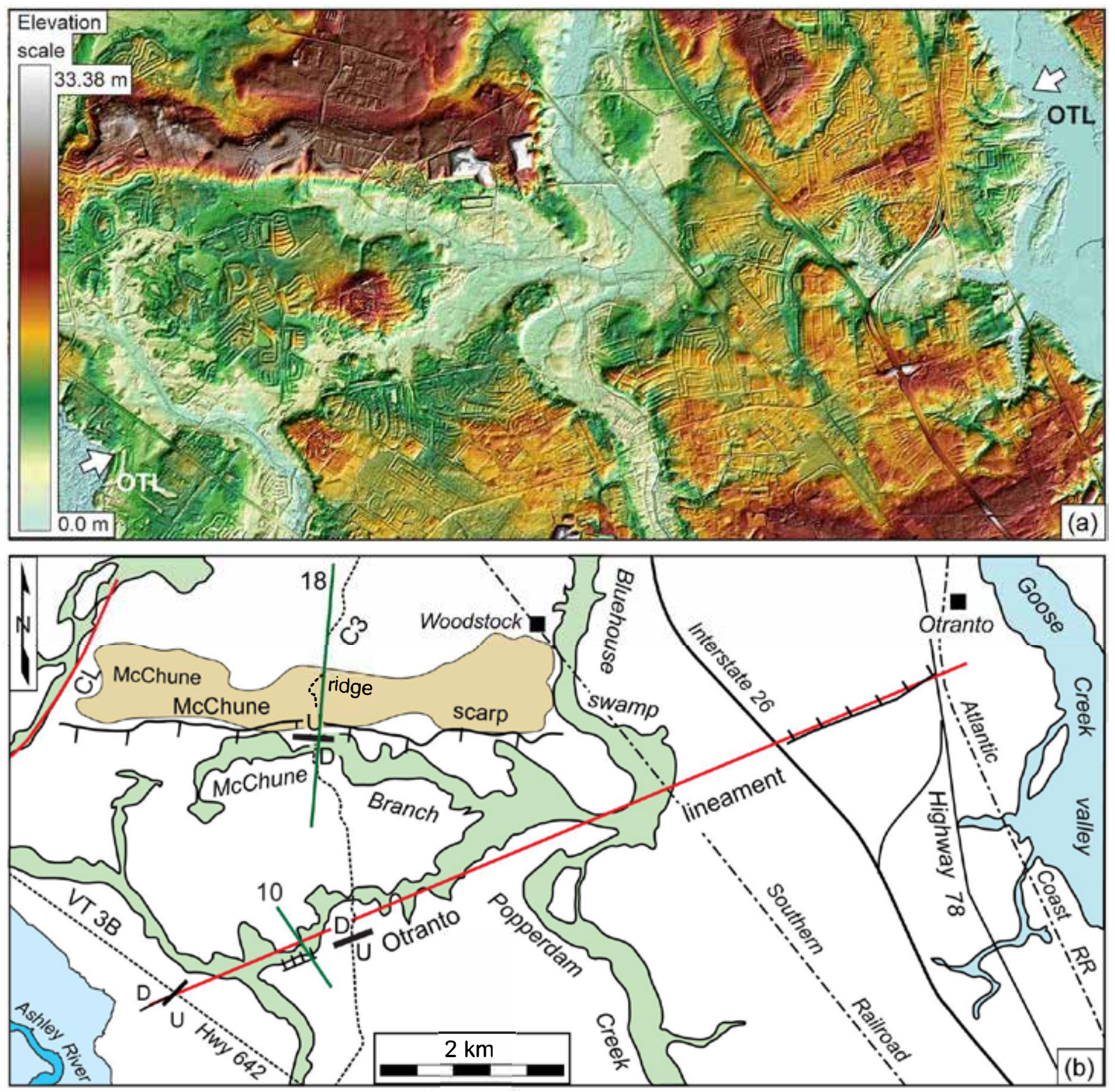

Figure 9. (a) Color LiDAR image showing the Otranto lineament (OTL) between arrows. Illumination azimuth is $140^{\circ}$. (b) Map for image (a). Green line is an elevation profile shown in Figure 5. Seismic-reflection profiles C3 and VT3B show interpreted faults along the OTL and the McChune scarp (U on upthrown side). CL is the Coosaw Creek lineament.

of the Woodstock epicenter (Fig. 4b, site S2) and the area of compressional ground bulges along the Atlantic Coast Railroad just north of this area in 1886 (page 291 of Dutton 1890) (Fig. 4b, site S1) suggests that the fault associated with the 1886 earthquake crosses this area. Third, the $40-\mathrm{km}$ length of the Deer Park lineament is long enough to have been associated with such a large earthquake. Four, analyses of building damage in parts of Charleston by G.E. Manigault suggest that the seismic waves from the main shock came from the northwest and north (page 96 of Peters and Herrmann 1986), which favors displacement along an E-Woriented fault long enough to have produced seismic waves from across the northern part of the meizoseismal area, like that associated with the Deer Park lineament. Moreover, the orientation of the Deer Park lineament relative to $\mathrm{S}_{\text {Hmax }}$ (Fig. 14) favors sinistral strike-slip displacement along the postulated fault. Five, we postulate that the Foster Creek depression (Figs. 3 and 6) is evidence for increased erosion caused 

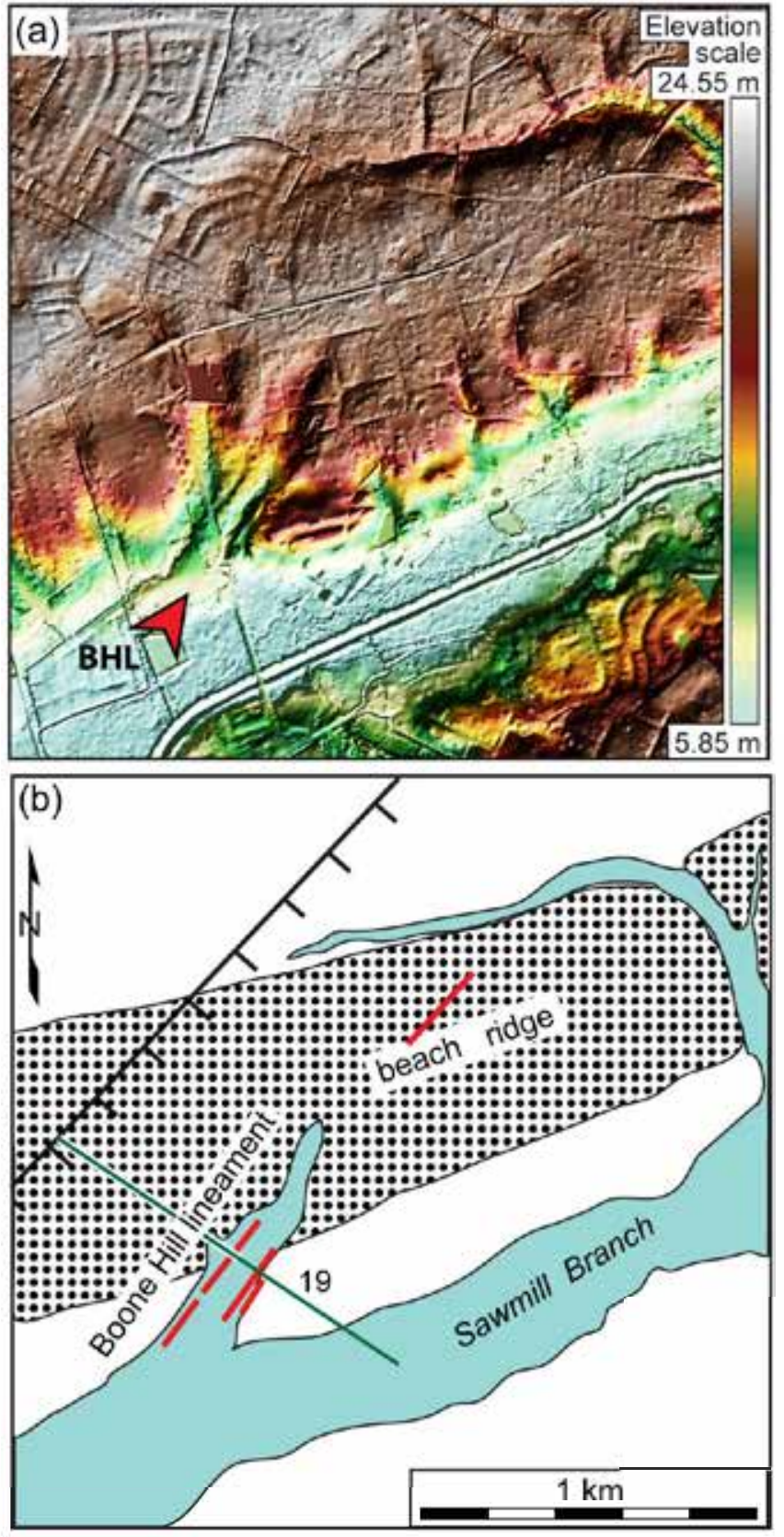

Figure 10. (a) Color LiDAR image showing part of the Boone Hill lineament (BHL, NE-directed arrow). Illumination azimuth is $140^{\circ}$. (b) Map for image (a). The green line is an elevation profile shown in Figure 5. Red lines are linear depressions that collectively define the Boone Hill lineament.

by a broad zone of fractures along the trend of the Deer Park lineament. Finally, the southward movement of the crust east of the Woodstock fault to the north favors additional loading of strain on the fault associated with this lineament (Fig. 14) until it eventually ruptures in an earthquake.

Several observations suggest that the interpreted fault along the Middleton Place lineament may also have ruptured in 1886, although its $17-\mathrm{km}$ length is too short for the main shock to have occurred along it. First, it is located near the Middleton Place epicenter (Fig. 14). Secondly, recent deformation is supported by the convex-up Popperdam Creek valley floor where it crosses the Middleton Place lineament (Fig. 5, profiles 11-17). Third, the shallow, water-filled linear depressions along the southwestern end of the Middleton Place lineament (Fig. 7c) are developed within Holocene swamp deposits (Weems et al. 2014). Similar shallow linear depressions were also noted along part of the Bootheel fault trace in the New Madrid seismic zone (Marple and Schweig 1992, figure 5). Lastly, the Middleton Place lineament crosses the Atlantic Coast Railway where a significant flexure developed in the tracks during the 1886 earthquake (Fig. 3b, site S3).

The upwarped valley floors of the Sophia and Brick Bound swamps across the Mount Holly lineament, the increased incision of the Sophia Swamp, and the interpreted 200-m-wide topographically high area between the Sophia and Brick Bound swamps (Figs. 3b and 5, profiles 22-25) suggest that late Pleistocene or Holocene deformation has also occurred along this lineament. The Wando Formation sediments present along Sophia Swamp north of the lineament (Fig. 5, profile 22) suggests that uplift has been sufficient to cause any estuarine sediments that may have once existed along this part of the swamp to be eroded away. Despite the evidence for Holocene deformation along the Mount Holly lineament, it is unlikely that the interpreted fault associated with this lineament ruptured in 1886 because it does not cross the main area of earthquake damage (Fig. 14).

\section{Association of lineaments with domal uplift}

The coincidence of the Dawson, Magnolia Gardens, and Lambs lineaments along the Ashley River valley with the Fort Bull dome (Fig. 14) suggests that late Cenozoic uplift along these lineaments produced this dome. The local terraces along the Ashley River valley that are developed in the late Pleistocene Wando Formation (Figs. 1 and 5, profile 21) support this conclusion. The entrenched lower Popperdam Creek valley where it converges with the Ashley River valley (Fig. 5, profile 16) is also likely from Quaternary uplift along the Fort Bull dome (Fig. 1). The orientation of the NW-SE-oriented lineaments with respect to $S_{\mathrm{H} \max }$ favors further reverse displacement along these interpreted NW-SE-oriented faults. The coincidence of the Canterhill lineament, which we postulate is the surface expression of the Charleston fault, with the southwestern edge of the Mount Holly and Mount Pleasant domes (Fig. 14) suggests that this interpreted fault has also undergone NE-side-up Quaternary displacements.

\section{Evidence for active tectonics near Summerville}

Although instrumentally recorded seismicity along the Woodstock fault near Summerville shows that this part of the fault is currently active (Fig. 1), little modern seismicity has occurred along the fault to the northeast where repeated 


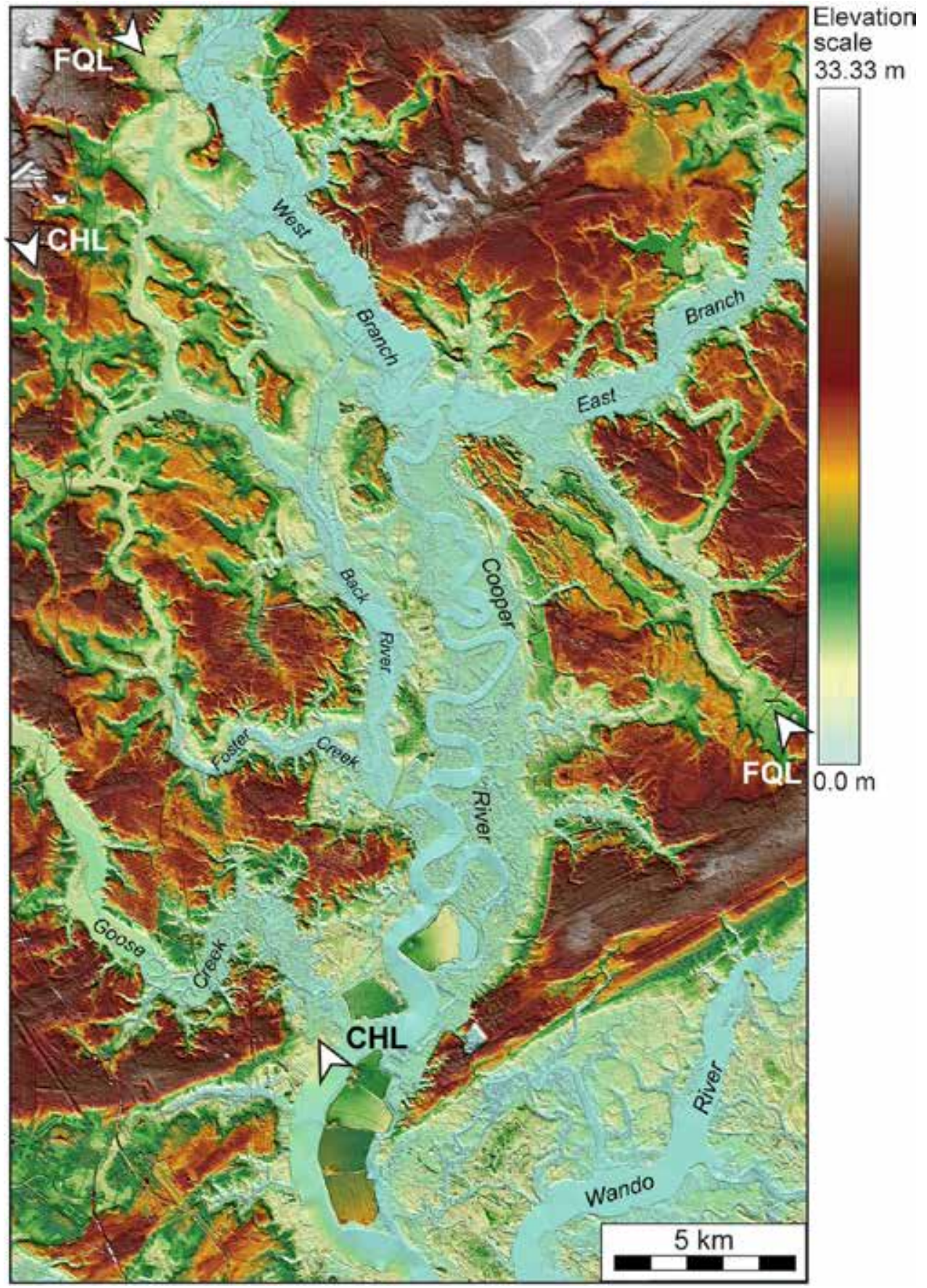

Figure 11. Color LiDAR image showing the Canterhill (CHL) and French Quarter Creek (FQL) lineaments. Illumination azimuth is $200^{\circ}$. Location of image is shown in Figure 14.

dextral displacements along the Woodstock fault have dextrally offset the middle Pleistocene beach ridge $\sim 350 \mathrm{~m}$ (Fig. 12). This observation suggests that numerous large earthquakes have occurred along the Woodstock fault northeast of Summerville in the past. The elevated middle Pleistocene beach ridges along the Penholoway terrace (Figs. 2, 12 , and 13 , profile 26 ) and the elevated pre-Pliocene surface beneath this area (Fig. 1) further support long-term deformation along the Woodstock fault. Despite the evidence for late Quaternary deformation along the Woodstock fault, the main shock in 1886 likely did not occur along this fault as it is located northwest of the worst earthquake damage in 1886 (Fig. 14).

We also postulate that the numerous 30 - to 100 -m-wide, 1- to 2-m-deep circular depressions in the northwestern part of the study area (e.g., Fig. 12) may be from earthquakeinduced liquefaction, which is outside the area of previously documented liquefaction (e.g., Talwani and Schaeffer 2001). These depressions are not likely Carolina bays since they are commonly circular, rather than elliptical like most Carolina 

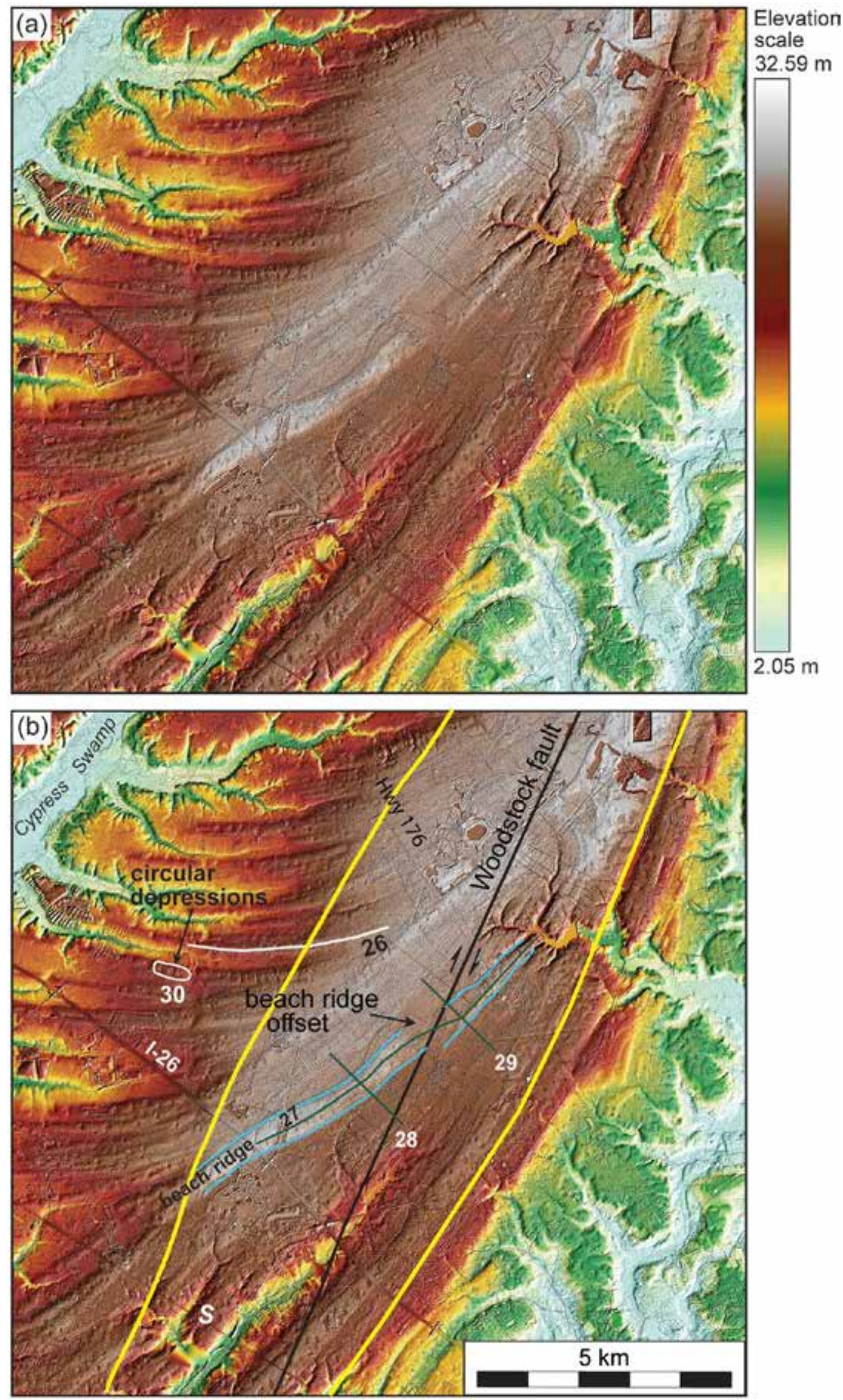

Figure 12. (caption on next page) 
Figure 12. (previous page) (a) Color LiDAR image of part of the Penholoway terrace. Illumination azimuth is $120^{\circ}$. Location of image is shown in Figure 14. (b) Interpreted version of image (a) showing elevated beach ridges across the Penholoway terrace, one of which is dextrally offset along the Woodstock fault. Dark green lines are elevation profiles shown in Figure 13. Elevation profile 26 (white line) is along a portion of a beach ridge. Elevation profile of circular depressions at location 30 are shown in Figure 13. Thick yellow contours show the area of uplift interpreted from the elevated beach ridges. $S$ is Summerville.

bays (e.g., Moore et al. 2016). If true, then these features may be surface expressions of sand blows associated with large earthquakes along the Woodstock fault northeast of Summerville.

\section{Holocene deformation along the Mount Holly lineament}

Evidence for Holocene deformation along the Mount Holly lineament is based mainly on the upwarped valley floors of the Brick Bound and Sophia swamps where they intersect the lineament (Fig. 5, profile 22). The V-shaped
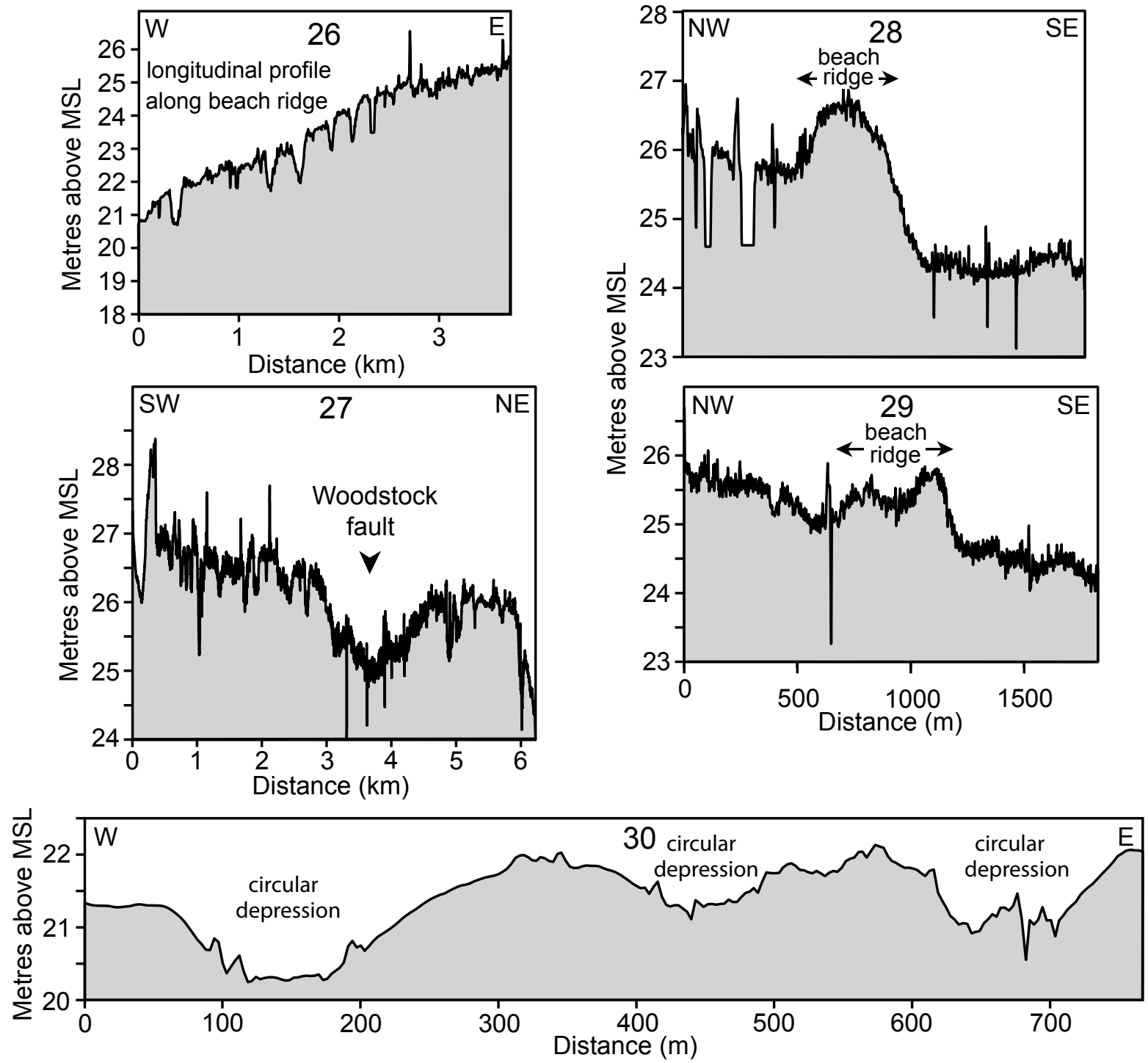

Figure 13. Elevation profiles along and across portions of two beach ridges north of Summerville (profiles 26-29). Profile 30 crosses three examples of circular depressions that are common throughout most of the study area.

floor of Sophia Swamp compared to the relatively flat floor of Brick Bound Swamp on opposite sides of the lineament and the exposed Wando Formation sediments along the $2.5-\mathrm{km}$ reach of the Sophia Swamp north of the lineament (Fig. 5, profiles 22-25) suggest that the Sophia Swamp is incising downward in response to uplift north of the Mount Holly lineament. We hypothesize that the 200-m-wide high area between the two swamps (Fig. 5, profile 22) is from local uplift along the lineament. If true, then these two swamps may have once been a continuous drainage system that has been disrupted by uplift along the Mount Holly lineament.

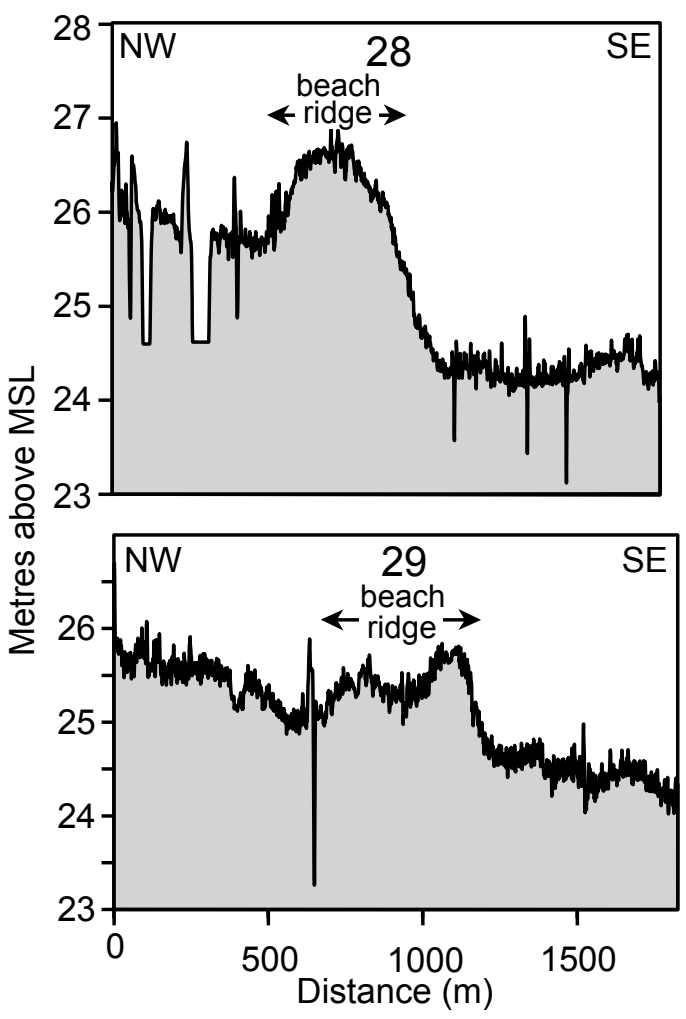




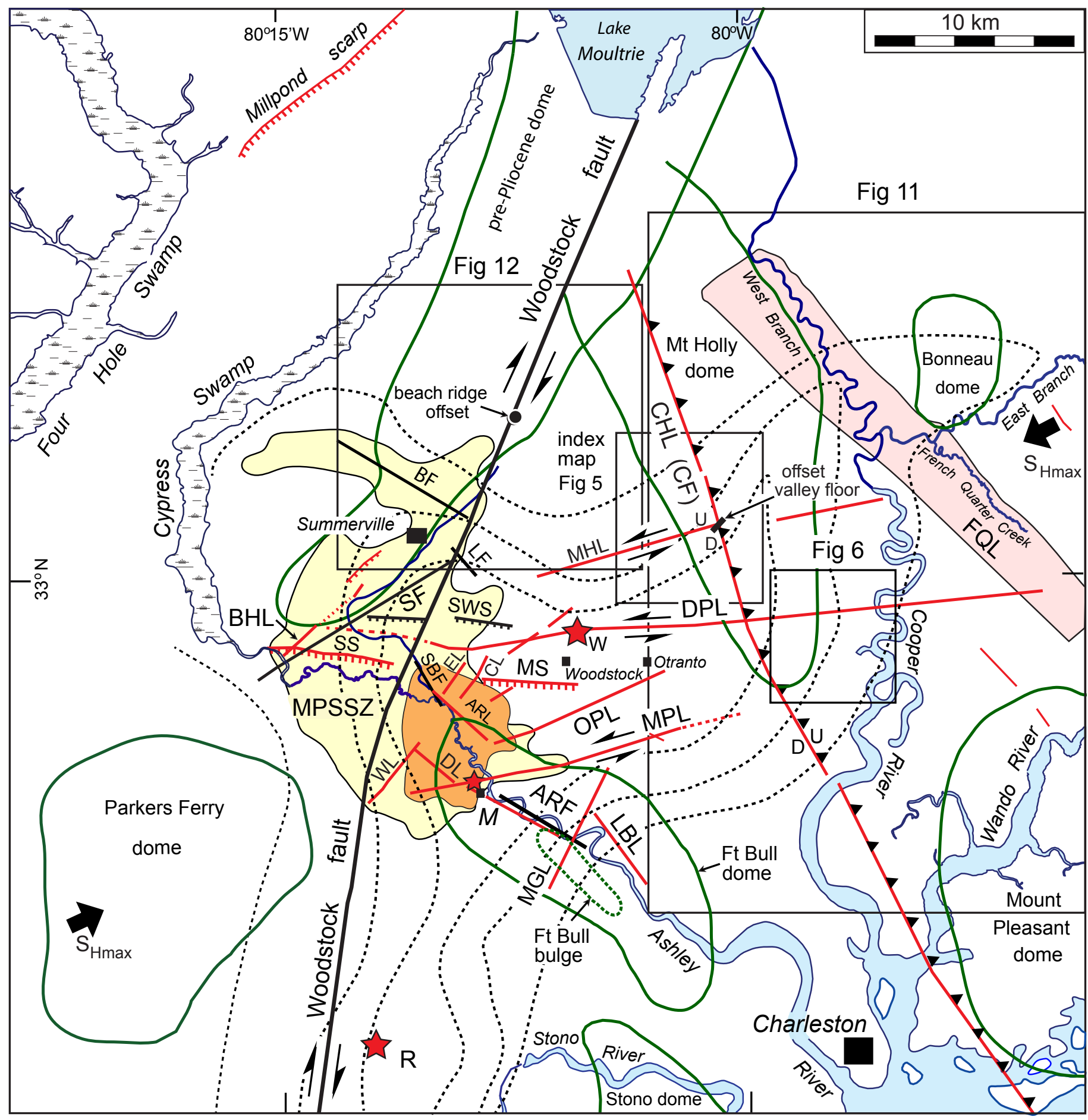

Figure 14. Summary map of LiDAR lineaments (red lines) and mapped faults (black lines) near the MPPSZ (orange and yellow patterns). Orange pattern is the greatest concentration of seismicity. See Tables 1 and 2 for abbreviations of faults, lineaments, and scarps. M, R, and W are the locations of epicenters proposed for the 1886 Charleston earthquake near Middleton Place, Rantowles, and Woodstock, respectively (Dutton 1890; McKinley 1887). The solid arrows labeled $S_{\mathrm{Hmax}}$ indicate the axis of maximum horizontal compressive stress field (Madabhushi and Talwani 1993). Dashed contours are Sloan's isoseismals from Dutton (1890). Structural domes (green contours) are from Weems and Obermeier (1989) and Weems and Lewis (2002). 


\section{Advantages of LiDAR data in urban and swampy areas}

The LiDAR data used in this study demonstrate that subtle tectonic lineaments can be interpreted even in areas where modern urbanization has modified the original landscape. The best two examples are the Deer Park and Middleton Place lineaments where they cross Deer Park and Ashley Heights, respectively (Figs. 4a and 8). Such features would be difficult to interpret using older conventional satellite images and aerial photos. LiDAR data are also useful for searching for evidence of faulting in swampy areas where it is often difficult to traverse the terrain on foot.

\section{CONCLUSIONS}

In conclusion, we hypothesize that most of the LiDAR lineaments in the study area are associated with active faults that ruptured the ground surface either in 1886 or during previous Holocene earthquakes. The greater concentration of interpreted faults east of the bend in the Woodstock fault suggests that they are associated with compressional stresses caused by dextral motion along the fault bend. We postulate that the main shock of the 1886 Charleston, South Carolina, earthquake may have been caused by sinistral strike-slip displacement along the 40-km-long, ENE-WSE-oriented Deer Park lineament based on its orientation relative to $\mathrm{S}_{\text {Hmax }}$ and its close proximity to the Woodstock epicenter. The proposed 17-km-long Middleton Place fault may have also ruptured in a smaller earthquake in 1886 based on its proximity to the Middleton Place epicenter and a severe flexure that developed in the Atlantic Coast Railroad tracks where they intersect the eastern end of the Middleton Place lineament. Despite the lack of seismicity east of the MPSSZ, the Fort Bull dome along the Ashley River fault zone and the Mount Holly and Mount Pleasant domes along the northeastern side of the Canterhill lineament (Charleston fault) indicates that these faults have been active during the late Tertiary. Evidence for late Quaternary deformation along the Woodstock fault north of the Ashley River includes the elevated beach ridges and the $\sim 350-\mathrm{m}$ dextral offset of the middle Pleistocene beach ridge along the Woodstock fault, which indicates that the fault has ruptured the ground surface numerous times in the past. Lastly, the numerous 30-100-m-size shallow circular depressions that exist across the study area are likely related to earthquake-induced liquefaction, rather than Carolina bays.

Further geological and geophysical studies are needed to document faulting along the LiDAR lineaments and to better estimate the seismic hazard potential of the Charleston region because of the recent large increase in population in the meizoseismal area of the 1886 Charleston earthquake. A large earthquake today in the Charleston region would likely cause tremendous damage and loss of life.

\section{ACKNOWLEDGEMENTS}

We thank reviewers Randy Cox and John Adams for their many constructive comments that helped improve this paper. We also thank Atlantic Geology editor Sandra Barr for her scientific feedback and help in formatting this manuscript.

\section{REFERENCES}

Bakun, W.H. and Hopper, M.G. 2004. Magnitudes and locations of the 1811-1812 New Madrid, Missouri, and the 1886 Charleston, South Carolina, earthquakes. Bulletin of the Seismological Society of America, 94, pp. 64-75. https://doi.org/10.1785/0120020122

Bollinger, G.A. 1977. Reinterpretation of the intensity data for the 1886 Charleston, South Carolina, earthquake. In Studies related to the Charleston, South Carolina, earthquake of 1886-A preliminary report. Edited by D.W. Rankin. United States Geological Survey, Professional Paper 1028, pp. 17-32.

Chapman, M.C. and Beale, J.N. 2008. Mesozoic and Cenozoic faulting imaged at the epicenter of the 1886 Charleston, South Carolina, earthquake. Bulletin of the Seismological Society of America, 98, no. 5, pp. 2533-2542. https://doi. org/10.1785/0120080923

Chapman, M.C. and Beale, J.N. 2010. On the geologic structure at the epicenter of the 1886 Charleston, South Carolina, earthquake. Bulletin of the Seismological Society of America, 100, pp. 1010-1030. https://doi. org/10.1785/0120090231

Chapman, M.C., Beale, J.N., Hardy, A.C., and Wu, Q. 2016. Modern seismicity and the fault responsible for the 1886 Charleston, South Carolina, earthquake. Bulletin of the Seismological Society of America, 106, no. 2, pp. 364372. https://doi.org/10.1785/0120150221

Colquhoun, D.J., Johnson, G.G., Peebles, P.C., Huddlestun, P.F., and Scott, T. 1991. Quaternary geology of the Atlantic Coastal Plain. In Quaternary nonglacial geology: Conterminous U.S.: Geology of North America. Edited by R.B. Morrison. Geological Society of America, Boulder, Colorado, USA, K-2, pp. 629-650. https://doi.org/10.1130/ DNAG-GNA-K2.629

Colquhoun, D.J., Woollen, I.D., Van Nieuwenhuise, D.S., Padgett, G.G., Oldham, R.W., Boylan, D.C., Howell, P.D., and Bishop, J.W. 1983. Surface and subsurface stratigraphy, structure and aquifers of the South Carolina Coastal Plain: Columbia, State of South Carolina, Office of the Governor, Ground Water Protection Division, Report for Department of Health and Environmental Control, 78 p.

Cunningham, W.D. and Mann, P. (Editors). 2007. Tectonics of strike-slip restraining and releasing bends. Geological Society of London, Special Publications number 290, 482 p. https://doi.org/10.1144/SP290.0

Daniels, D.L., Zietz, I., and Popenoe, P. 1983. Distribution of subsurface lower Mesozoic rocks in the southeastern 
United States as interpreted from regional aeromagnetic and gravity maps. In Studies related to the Charleston, South Carolina, earthquake of 1886-Tectonics and seismicity. Edited by G.S. Gohn. United States Geological Survey, Professional Paper 1313-K, 24 p.

DNR. 2019. South Carolina Department of Natural Resources: LiDAR and related data products. URL $<$ http:// www.dnr.sc.gov/GIS/lidar.html>, 1 November 2019.

Du, Y. and Aydin, A. 1996. Is the San Andreas big bend responsible for the Landers earthquake and the eastern California shear zone? Geology, 24, no. 3, pp. 219-222. https://doi.org/10.1130/0091-7613(1996)024<0219:IT $\underline{\mathrm{SABB}}>2.3 . \mathrm{CO} ; 2$

Durá-Gómez, I. and Talwani, P. 2009. Finding faults in the Charleston area, South Carolina: 1. Seismological data. Seismological Research Letters, 80, pp. 883-900. https:// doi.org/10.1785/gssrl.80.5.883

Dutton, C.E. 1890. The Charleston earthquake of August 31, 1886. United States Geological Survey, Ninth Annual Report, $528 \mathrm{p}$.

Hamilton, R.M., Behrendt, J.C., and Ackermann, H.D. 1983. Land multichannel seismic reflection evidence for tectonic features near Charleston, South Carolina. In Studies related to the Charleston, South Carolina, earthquake of 1886-Tectonics and seismicity. Edited by G.S. Gohn. United States Geological Survey, Professional Paper 1313I, $18 \mathrm{p}$.

Johnston, A.C. 1996. Seismic moment assessment of earthquakes in stable continental regions-III, New Madrid 1811-1812, Charleston 1886 and Lisbon 1755. Geophysical Journal International, 126, pp. 314-344. https://doi. org/10.1111/j.1365-246X.1996.tb05294.x

King, G. and Nábělek, J. 1985. Role of fault bends in the initiation and termination of earthquake rupture. Science, 228, pp. 984-987. https://doi.org/10.1126/science.228.4702.984

Lennon, G. 1986. Identification of a northwest trending seismogenic graben near Charleston, South Carolina. United States Nuclear Regulatory Commission Report NUREG/ CR-4705, pp. 1-43.

Madabhushi, S. and Talwani, P. 1993. Fault plane solutions and relocations of recent earthquakes in Middleton Place-Summerville seismic zone near Charleston, South Carolina. Bulletin of the Seismological Society of America, 83, no. 5, pp. 1442-1466.

Marple, R.T. and Hurd, J.D., Jr. 2020. Interpretation of lineaments and faults near Summerville, South Carolina, using LiDAR data and previously acquired seismic-reflection profiles: Implications for the cause of the 1886 Charleston, South Carolina, earthquake. Unpublished abstract of the Geological Society of America, Northeastern-Southeastern section meeting in Reston, Virginia. https://doi. org/10.1130/abs/2020SE-345392

Marple, R.T. and Miller, R. 2006. Association of the 1886 Charleston, South Carolina, earthquake and seismicity near Summerville with a $12^{\circ}$ bend in the East Coast fault system and triple-fault junctions. Southeastern Geology,
44, no. 3, pp. 101-128.

Marple, R.T. and Schweig, E.S., III. 1992. Remote sensing of alluvial terrain in a humid, tectonically active setting: The New Madrid seismic zone. Photogrammetric Engineering \& Remote Sensing, 58, no. 2, pp. 209-219.

Marple, R.T. and Talwani, P. 1993. Evidence of possible tectonic upwarping along the South Carolina Coastal Plain from an examination of river morphology and elevation data. Geology, 21, no. 7, pp. 651-654. https://doi. org/10.1130/0091-7613(1993)021<0651:EOPTUA >2.3. $\mathrm{CO} ; 2$

Marple, R.T. and Talwani, P. 2000. Evidence for a buried fault system in the Coastal Plain of the Carolinas and Virginia-Implications for neotectonics in the southeastern United States. Geological Society of America Bulletin, 112, no. 2, pp. 200-220. https://doi. org/10.1130/0016-7606(2000)112<200:EFABFS $>2.0$. $\mathrm{CO} ; 2$

McKinley, C. 1887. A descriptive narrative of the earthquake of August 31, 1886. In Appendix for the City (of Charleston) Year Book, 1886, pp. 345-441. Charleston, South Carolina: Walker, Evans, and Cogswell Company.

Moore, C.M., Brooks, M.J., Mallinson, D.J., Parham, P.R., Ivester, A.H., and Feathers, J.K. 2016. The Quaternary evolution of Herndon Bay, a Carolina Bay on the Coastal Plain of North Carolina (USA): Implications for paleoclimate and oriented lake genesis. Southeastern Geology, 51, no. 4, pp. 145-171.

Peters, K. and Herrmann, R.B. (Editors). 1986. First-hand observations of the Charleston earthquake of August 31, 1886, and other earthquake materials: Reports of W.J. McGee, Earle Sloan, Gabriel E. Manigault, Simon Newcomb, and others. South Carolina Geological Survey, Bulletin $41,116 \mathrm{p}$.

Rhea, S. 1989. Evidence of uplift near Charleston, South Carolina. Geology, 17, pp. 311-315. https://doi.org/10.11 30/0091-7613(1989)017<0311:EOUNCS >2.3.CO;2

Schilt, F.S., Brown, L.D., Oliver, J.E., and Kaufman, S. 1983. Subsurface structure near Charleston, South Carolina: Results of COCORP reflection profiling in the Atlantic Coastal Plain. In Studies related to the Charleston, South Carolina, earthquake of 1886-Tectonics and seismicity. Edited by G.S. Gohn. United States Geological Survey, Professional Paper 1313-H, 19 p.

Schwartz, S.Y., Orange, D.L., and Anderson, R.S. 1990. Complex fault interactions in a restraining bend on the San Andreas fault, southern Santa Cruz Mountains, California. Geophysical Research Letters, 17, no. 8, pp. 12071210. https://doi.org/10.1029/GL017i008p01207

Shedlock, K.M. 1988. Seismicity in South Carolina. Seismological Research Letters, 59, pp. 165-171.https://doi. org/10.1785/gssrl.59.4.165

Sieh, K.E. and Williams, P.L. 1990. Behavior of the southernmost San Andreas fault during the past 300 years. Journal of Geophysical Research, 95, pp. 371-379. https:// doi.org/10.1029/JB095iB05p06629

Talwani, P. 1982. An internally consistent pattern of seis- 
micity near Charleston, South Carolina. Geology, 10, pp. 655-658. https://doi.org/10.1130/0091-7613(1982)10<65 4:ICPOSN $>2.0 . \mathrm{CO} ; 2$

Talwani, P. and Schaeffer, W.T. 2001. Recurrence rates of large earthquakes in the South Carolina Coastal Plain based on paleoliquefaction data. Journal of Geophysical Research, 106, pp. 6621-6642. https://doi.org/10.1029/ 2000JB900398

Talwani, P. and Durá-Gómez, I. 2009. Finding faults in the Charleston area, South Carolina: 2. Complementary data. Seismological Research Letters, 80, pp. 901-919. https:// doi.org/10.1785/gssrl.80.5.901

Talwani, P., Hasek, M., Gassman, S., Doar, W.R., III, and Chapman, A. 2011. Discovery of a sand blow and associated fault in the epicentral area of the 1886 Charleston earthquake. Seismological Research Letters, 82, no. 4, pp. 589-598. https://doi.org/10.1785/gssrl.82.4.589

USGS. 2019. United States Geological Survey Earthquake Hazards Program: Earthquakes. URL < https://earthquake.usgs.gov/earthquakes/search/>, 15 December 2019.

Weems, R.E. and Lemon, E.M., Jr. 1984a. Geologic map of the Mount Holly Quadrangle, Berkeley and Charleston counties, South Carolina with text. United States Geological Survey, Geologic Quadrangle Map, GQ-1579, 1 sheet, scale 1:24000.

Weems, R.E. and Lemon, E.M., Jr. 1984b. Geologic map of the Stallsville Quadrangle, Charleston and Dorchester counties, South Carolina: United States Geological Survey, Miscellaneous Investigations Map, GQ-1581, 1 sheet, scale 1:24000.

Weems, R.E. and Lemon, E.M., Jr. 1988. Geologic map of the Ladson Quadrangle, Berkeley, Charleston, and Dorchester counties, South Carolina. United States Geological Survey, Miscellaneous Investigations Map, GQ-1630, 1 sheet, scale 1:24000.

Weems, R.E. and Lemon, E.M., Jr. 1989. Geology of the
Bethera, Cordesville, Huger, and Kittredge quadrangles, Berkeley County, South Carolina. United States Geological Survey, Miscellaneous Investigations Map, IMAP1854, 2 sheets, scale 1:24 000.

Weems, R.E. and Lemon, E.M., Jr. 1993. Geology of the Cainhoy, Charleston, Fort Moultrie, and North Charleston quadrangles, Charleston and Berkeley counties, South Carolina. United States Geological Survey, Miscellaneous Investigations Map, IMAP-1935, 2 sheets, scale 1:24 000.

Weems, R.E. and Lewis, W.C. 2002. Structural and tectonic setting of the Charleston, South Carolina, region: Evidence from the Tertiary stratigraphic record. Geological Society of America Bulletin, 114, pp. 24-42. https://doi. org/10.1130/0016-7606(2002) 114<0024:SATSOT $>2.0$. $\underline{\mathrm{CO} ; 2}$

Weems, R.E. and Obermeier, S.F. 1989. The 1886 Charleston earthquake-An overview of geological studies. In Proceedings of the United States Nuclear Regulatory Commission, Seventeenth Water Reactor Safety Information Meeting, October 23-25, 1989, Rockville, Maryland. United States Nuclear Regulatory Commission, Report No. NUREG/CP-0105, 2, pp. 289-313.

Weems, R.E., Lemon, E.M., Jr., and Nelson, M.S. 1997. Geology of the Pringletown, Ridgeville, Summerville, and Summerville Northwest 7.5-minute quadrangles, Berkeley, Charleston, and Dorchester counties, South Carolina. United States Geological Survey, Miscellaneous Investigations Series, Map I-2502, 2 sheets, scale 1:24 000.

Weems, R.E., Lewis, W.C., and Lemon, E.M., Jr. 2014. Surficial geologic map of the Charleston region, Berkeley, Charleston, Colleton, Dorchester, and Georgetown counties, South Carolina: United States Geological Survey, Open-File Report 2013-1030, 1 sheet, scale 1:100 000. URL < http://dx.doi.org/10.3133/ofr20131030>, 1 February 2020 .

Editorial responsibility: Sandra M. Barr 